\title{
Influence of Pathogens on Disease Development with Various Crops Grown in Zoba-Anseba, Eritrea during 2007-2017: A Report
}

\author{
Syed Danish Yaseen Naqvi* and G. Sethumadha A Rao
}

Department of Plant Protection, Hamelmalo Agricultural College, Keren, Eritrea

*Corresponding author

Keywords

Pathogens,

Vegetable crops,

Field crops, Disease

influence, Zoba-

Anseba

Article Info

Accepted:

07 December 2018

Available Online:

10 January 2019

\section{A B S T R A C T}

This compilation includes various diseases observed in Zoba-Anseba, Eritrea during a decade of time from 2007-2017. The total productive area of horticultural farms in this Zoba is over 26,885 ha and it is one of the most drought-prone regions of Eritrea. Farmers grow crops such cereals, oil seeds, vegetables and fruits etc. Enormous pathogens such as fungi, bacteria and other microbes; nematodes, and intervention of migratory insect pests cause a lot of damage to these crops and finally it leads in yield loss. In spite of application of chemicals, various botanical extracts also in practice to control some of these diseases. The methodologies used in this research were surveys, field experiments, diseases assessments and isolation of pathogens. Most of the fungal pathogens were identified and recorded their occurrence from various parts of the plants, at different phenological stages and also from the soils of these crops cultivated.

\section{Introduction}

This compendium includes the descriptions and illustrations of identified diseases and pests on various crops cultivated in ZobaAnseba, Eritrea. It is estimated that 463,926 hectares of arable area is under cereal cultivation in Eritrea (Gran do, et al., 2010). About $80 \%$ of the Eritrean farmers depend on mixed farming systems and rain-fed agriculture. However, a wide range of crops are gr own in this country under rainfed production system (AAT F 2011). T e soil profile of the sub-zoba is predominantly sandy loam with low water retention capacity and
pH 6 -7 (MoA, 2014). Another report of MoA, 2012 mentions $t$ at the major soil types in Eritrea are the Cambisols, Lithosols, Fluvisols, Regosols and Cambisols.

Eritrea is situated in the horn of East Africa and has a total area of 124,320 square kilometers. It is bordered in the north and west by Sudan, in the south by Ethiopia and Djibuti and in the east by the Red Sea, The country (capital town-Asmara), has six administrative provinces (called obas) viz. Anseba, Debub, Gash barka, Maekel, Northern Redsea and Southern Redsea and is having into 529 villages. Figure 1 shows the $15 \%$ of land is 
under cultivation of the total arable land, Zoba-Anseba, with a capital town Keren, is situated in the north western part of Eritrea and it covers an area of 22,834 square kilometers. The total productive area of horticultural farms in this Zoba is over 26,885 ha, Anseba is one of the most drought-prone regions of Eritrea as annual rain fall is low, very erratic and it is divided into 11 subzobas.

Important cereal crops in this country are: sorghum (locally called Machala), pearl millet (Bultuk), barley (Segem), finger millet (Dagusha), taff (Taff), maize (Offun), wheat (Sernay), chickpea and groundnut (Grando, et $a l ., 2010)$. On the other hand, the vegetable crops are tomato (Komedero), potato (Dineesh), chilli (Beryberi), okra (Baamia), eggplant (Aswa), cabbage (Caulov), cauliflower (Fiori-caulov), zucchini, lettuce, molukya and onion (sukruthi); and the horticultural crops are rose, citrus, grapes and mangoes. The total vegetables grown in this sub-Zoba are tomato and chillis accounting for $47 \%$ of the total crop produced.

Sorghum (Sorghum bicolor L.) (Poaceae family) is a native of Africa in the south of the Sahara desert. According to ASARECA, (2004) and Rohrbach, (2004), sorghum is grown on approximately 10 million ha and millets on over 3 million ha, in Eastern and Central Africa, all accounting for about 56\% of cereal acreage and $41 \%$ of cereal production.

In Eritrea, Sorghum is the most important and widely grown cereal crop, especially in the lowlands. Sorghum ranks first in the contribution towards national economy, diet and on an average $45 \%$ of the bulk total food production for the nation. In the Anseba region, according to Anon, 2002, till 2001 the area cultivated under sorghum and groundnut was about 20,178 hectares with a production of about 8442.1 tonnes. Pearl millet [Pennisetum glaucum (L.) R. Br.] is the second most important cereal grown after sorghum in Eritrea, and is grown on 17,000 hectare (AATF 2011) and indigenous to North Africa (D'Andrea, et al., 2001). In 2000, one of the investigations done by Bhasker et al., (2000), more than $50 \%$ of pearl millet plants surveyed in Anseba and Gash Barka were found to be infected with downy mildew caused by Sclerospora graminicola (Sacc.) J. Schröt. and caused major yield losses, estimated at $30 \%$ in Anseba in 2000.

Some of the economically important vegetables of Eritrea produced in sub-zobas Adi-Tekeliezan, Hamelmalo and Hagaz of Zoba Anseba are: Tomato (Lycopersicon esculentum L.); Potato (Solanum tuberosum L.); Chilli (Capsicum annum L.) and Eggplant (Solanum melongena L.); Okra (Abelmoschus esculentus Moench) and Jute mallow (Corchorus olitorious) and Lettuce (Lactuca sativa).

Tomato (Lycopersicon esculentum Mill) belongs to the Solanaceae family. In Eritrea, the main tomato production areas are Hamelmao, Keren, Elabred, Hagaz and Zoba Maekel and it is considered a major component in the diets of majority of Eritreans. According to Mario, 1997, the most commonly grown varieties of tomatoes are Sanmarzano, Chico3, Roma VF, Riogrande and Marglobe. According to Ministry of Agriculture (MoA, 2012), the area of cultivation tomato (3740 ha) and its production is $96228 \mathrm{mt}$ in Eritrea, whereas, in Zoba-Anseba the production of tomato is 6663 $\mathrm{mt}$ in an area of 617 ha. Chillies (Capsicum annuиm L.) are used either in green or as dried fruits of pungent forms which are widely cultivated throughout the world, and also as the most popular vegetable crop in zobaAnseba. The cultivation of chilli, is an area of 3550ha in the country but in Zoba-Anseba it is 
only 300ha with the $874 \mathrm{mt}$ of production. Besides fungal and bacterial diseases, Chilli veinal mottle virus (ChiVMV) has also been found recently in East Africa (Nono-Womdim et al., 2001). The natural hosts of ChiVMV are sweet and hot pepper (Capsicum spp.), tomato (Lycopersicon esculentum), and African eggplant (Solanum aethiopicum) and this virus is transmitted in a non-persistent manner by several aphid species (Ong et al., 1979). However, it is also mechanically transmitted.

In Africa citrus is cultivated in 551.95 thousand ha with a total production of 8.400 thousand tones with production share of 8.3 percent (FAO, 2007). In Eritrea, according to the statistics of MoA, 2003, the average yield of orange, lemon and mandarin $10.7 \mathrm{t} \mathrm{ha}^{-1}$, 14.0 $\mathrm{tha}^{-1}$ and $4.3 \mathrm{t} \mathrm{ha}^{-1}$ respectively in the cultivated area.

Average yield per hectare for all citrus is around $10.0 \mathrm{t} \mathrm{ha}^{-1}$ international averages. A wide range of tropical fruit crops i.e., mango are cultivated along the banks of the river 'Anseba' production (MoA, 1995 and Leipzig, 1996). More than 70 diseases have been reported from groundnut due to fungi, bacteria, viruses, nematodes, etc (Lukose et al., 2008). Like field crops, vegetable crops are also affected by a plethora of pathogens which results in unmarketability. Among the pests, fungi are one of the significant factors in damaging grains, fruits, vegetables and storage food commodity and also reduce seed viability. Besides, there are many other diseases occurring in these sub-zobas on various vegetable crops (Syed et al., 2014 and Sethumadhava Rao et al., 2016) about which more information is necessary for boosting production. As it is known, the infectious pathogens such as fungi, bacteria and other microbes; nematodes, and intervention of migratory insect pests cause a lot of damage to the crops. Due to the infections caused by these pathogens, the plants get sick, which lead to weakness as shown in physiological activities, metabolism and finally it results in yield loss. When unfavorable environmental conditions are considered this will be doubled or more. It is difficult to know exactly when a plant is infected because it is unknown until the symptoms are visible on the plant surface. Viral infections are 'latent' and 'masked' which are transmitted by vectors. In the case of nematode infections, the symptoms appear after the penetration by them into roots which are called 'hidden enemies'. The water transportation in xylem and movements of photosynthates in phloem are blocked due to the accumulation of inoculums in the vascular bundles. Whatever pathogens are causing the diseases, the symptomotology gives us the intensity rate of the crops to analyze the epidemics. As pest control, aqueous extracts of flowers, cloves, leaves, bark, root and seed of different plants have been used to control the diseases. Onion, garlic and ginger are some of the most important botanical pesticides which are more effective and easily available as compared to synthetic pesticides. Garlic due to the presence of diallyl sulfide and triallyl sulfide shows fungicidal property against seed borne fungus. Mancozeb belongs to thiocarbamates fungicides containing Manganese and Zinc and it is very effective against seed borne diseases especially in blight, seed rot, damping off and wilt etc.

Nowadays, many of the farmers use fungicides, nematicides and insecticides to minimize the diseases. The continuous use of chemicals has posed a serious threat to the environment and resulted in repercussions on the ecosystem. To avoid excess application of chemicals and post applications residue which will remain on the produce, it is better to switch to use plant extracts for controlling the disease. Research is still going on regarding the efficacy of various botanicals and biopesticides to control the diseases. For 
example, Trichoderma viride (Singh et al., 2003 and Sonawane and Pawar, 2001) or the combination of Trichoderma harzianum and Trichoderma viride (Syed, 2012) resulting in significant reduction in the growth of Fusarium oxysporum f.sp. ciceri which is one of the causal agents of fusarial wilts of chickpea (Cicer arietinum L.). The highest inhibitory effect of Trichoderma spp. (radial growth $42.67 \mathrm{~mm}$ ) was reported against Fusarium oxysporum f.sp. ciceri at different intervals. In this report, the overall results were based on the investigations, observations in the field, examinations in the lab, intensive surveys and direct interviews done in various regions where these crops are grown. Newly described diseases and insects are also described briefly, so this serves to alert the experts to take the necessary action (Fig. 3).

\section{Materials and Methods}

\section{Experimental location}

All experiments were conducted in the Laboratory and field of Plant Protection, Hamelmalo Agricultural College, Eritrea. Hamelmalo is located at $12 \mathrm{~km}$ north east of Keren town on the bank of the river Anseba at $15^{\circ} 53^{\prime} \mathrm{N}$ latitude and $38^{\circ} 66^{\prime} \mathrm{E}$ longitude and an elevation of $1292 \mathrm{~m}$ above sea level. ZobaAnseba falls under semi-arid midland region of the country (Fig. 2). Annual rainfall, in the past six years, of this region ranged from 370 $\mathrm{mm}$ to $663.1 \mathrm{~mm}$ with a mean value of 488 $\mathrm{mm}$ (Anonymous, 1997). The temperature of the area varies from $16^{\circ} \mathrm{C}$ to $38^{\circ} \mathrm{C}$ during the winter and summer seasons and has an average of $27^{\circ} \mathrm{C}$. The soil of Zoba-Anseba is sandy and sandy loam with low water retention capacity and $\mathrm{pH}$ of 6-7 (Anonymous, 2000).

\section{Survey}

For survey, methodologies of James (1971 and 1974), and Weeks et al., (2000) were followed.

\section{Disease assessments}

Both dis ease incidence and disease severities (intensity) were assessed according to Jagtap et al., 2012.

\section{Disease incidence}

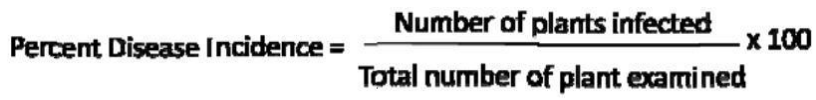

Disease Intensity was recorded and calculated using the following formula: (Davis et al., (1993).

Disease intensity $(\%)=\{[\mathrm{B} /(\mathrm{A} \times 9)] \times 100\}$

where, $\mathrm{B}=$ total disease rating, $\mathrm{A}=$ total number of samples and $9=$ maxi um grade as shown below for different diseases:

Table.1

\begin{tabular}{|c|c|c|c|c|}
\hline $\begin{array}{l}\text { Percentage of } \\
\text { infected leaf/unit } \\
\text { area of Leaf Spots* }\end{array}$ & $\begin{array}{l}\text { Percentage of } \\
\text { infected head/unit } \\
\text { area of Smuts\# }\end{array}$ & $\begin{array}{l}\text { Rating } \\
\text { grade } \\
(\mathrm{P})^{\$}\end{array}$ & $\begin{array}{l}\text { Number of } \\
\text { leaves/u nits in } \\
\text { the grade }(\mathrm{Q})\end{array}$ & $\begin{array}{l}\text { Rating of } \\
\text { Dis ease } \\
\text { (PXQ) }\end{array}$ \\
\hline $0.5-1 \%$ & 0 & 1 & & \\
\hline $1-5 \%$ & $1-10 \%$ & 3 & & \\
\hline $6-20 \%$ & $\begin{array}{c}11 \\
35 \%\end{array}$ & 5 & & \\
\hline $21-50 \%$ & $36-50 \%$ & 7 & & \\
\hline$>50 \%$ & $>0 \%$ & 9 & & \\
\hline Total & & & A & B \\
\hline
\end{tabular}




\section{Inoculation and incubation techniques}

The See d germination was done by standard blotter method which was developed by Doyer in 1938, later included in the International Seed Testing Association Rules of 1966. T e experiments were done in the $\mathrm{Pl}$ ant Protection Agricultural College, Eritrea.

\section{Isolation of fungi}

Potato Dextrose Agar (PDA) as a Nutrient Medium was used for fungal isolation (Aina $e t$ al., 2011). The $\mathrm{pH}$ of the medium acidified with $25 \%$ lactic acid was maintained at 5.5 , it being optimal or the growth and sporulation of fungi. The Soil Plate Method (Warcup, 1950) a d Serial Dilution Method (Waksman, 1922) on PDA media were used as isolation techniques.

\section{Identification of pathogens}

Fungal identifications were carried out on the basis of characterization of colonies and al so examining under microscope and consulting relevant literature (Aneja, 2004, Barnetad Hunter, 972, Ellis, 1971 Gilman, 1957; Raper and Fennell 1965 and Nagamani et al., 2006).

\section{Percent occurrence}

The percent contribution of each isolate as calculated by using the following formula: (Singh, 1 998).

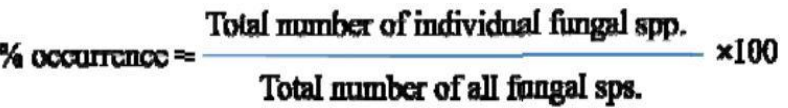

\section{Statistical analysis of data}

Data recorded about various parameters were statistically an analyzed GENST AT-10.3 (2011) with AN OVA at 5\% level of significance.

\section{Results and Discussion}

In one of the studies an attempt was made to identify the occurrence of soil-borne mycoflora during different crop growth stage of sorghum and pearl millet crops in different villages of Hamelmalo region. Field mycoflora (Alternaia alternata, Aspergillus niger, Aspergillus terreus, Fusaium oxysporium, Phytophthora infestans, Rhizctonia solani and Pythium debaryanum) were isolated in the fields sorghum crop. Alternaria alternata, Aspergilus niger, Fusarium oxysporium, Penicillium chrysogenum, Phytophthora infestans, Rhizoctonia solani, Rhizopus stolonifer and Pythium debaryanum from the Basheri villa e from the soils of pearlmillet at various phenological stages. Fungal species Alternaria alternat, Aspergillus niger, A. flavus, Fusarium oxysporium, Penicillium chrysogenum, Phytophthora infestans, Cladosporium cladosporoides Pythium debaryanum and Rhizopus stolonifer isolated from both of pearl millet and sorghum fields of Wazentit village of Hamelmalo sub-zoba. Among eleven fungal flora isolated from the field samples, the maximum incidence of fungal numbers $\left(\mathrm{cfu} / \mathrm{g} \times 10^{3}\right)$ of Pythium debaryanum was counted from the fields of pearl millet of Wazentit village (36) followed by Basheri village (31) (Syed et al., 2016).

Maximum seed-borne infection by $A$. alternata and $F$. oxysporum showed between 21 and $64 \%$ among seed samples of sorghum and groundnut crops tested from different farmers of zoba-Anseba. Studies of Syed et al., 2012, stated that there was reduction in germination in the grains due to the increase of infection by these fungi.

The evaluation of fungicides and garlic extracts against seed borne fungal pathogen of sorghum and groundnut revealed that the treatments of $4 \mathrm{gm}$ garlic extract $/ \mathrm{kg}$ seed was 
most effective which showed maximum seed germination $(96.70 \%)$ in sorghum and groundnut then, followed by germination of $(93.33 \%)$ in the treatments of (2 $\mathrm{g}$ garlic extract $+2 \mathrm{~g}$ mancozeb per $\mathrm{kg}$ seed) and (only 2 $\mathrm{g}$ mancozeb per $\mathrm{kg}$ seed), whereas in control (no treatment) the seed germination percentages were $76.7 \%$ in sorghum and $83.33 \%$ in ground nut. This result in support of Olkowski et al., (1995), that garlic extract spray has a broad spectrum effect and the seed treatment is effective and a cheap means of managing seed borne diseases in crops (Shenge, 2007). Similar findings of loss in seed germination percentage by Alternaria, Fusarium, Rhizopus, Aspergillus and Colletotrichum were reported by Agarwal and Sinclair (1997), Abdurahman (2005), Javid et al., (2006), Masum et al., (2008), Mesta et al., (2009), Rathod et.al., (2010).

In another study done by Syed et al., 2013 on seed-borne fungi, collected from three zobas (Anseba, Debub and Gashbarka) of Eritrea covering 14 villages, viz., Adinamn, Areza, Bashery, BeguDbarwa, Elabered, Endagergish, Golug, Hagaz, Hamelmalo, Hastina, Ksadeka, Oana, and Sabnait during August to November 2011, seven mycoflora were encountered in high percent frequencies of seed-borne fungal in the samples of sorghum, pearl millet and groundnut. Standard blotter method as described by the International Seed Testing Association (ISTA 1976), was used for the isolation of the seedborne fungi associated with stored seeds.

The results showed that for all the samples germination of sorghum was higher in ArayaHastina $(93.3 \%)$ followed by Brhane-Dbarba and Mhretab-Adinamm (92.0\%), Belay-Areza (90.7\%), Ahmedin-Sabnait (89.3\%), SieleHastina (84.0\%), Fshaye-Areza (76.0\%), Mensur-Hamelmalo (57.3\%), AbduHamelmalo (46.6\%) and Zeineb-Hamelmalo $(45.3 \%)$.
The identified fungal species were Alternaria, Aspergillus, Fusarium, Helminthosprium, Mucor, Penicillium and Rhizopus isolated from sorghum var. bushuka, shambuko, whereas in pearl millet var. hagaz, kona above fungal pathogens were identified except Mucor while in the seed samples of groundnut var. spanish valentia - Alternaria, Aspergillus, Fusarium, Helminthosprium and Rhizopus were detected. Similar results were collaborated with the research of Mathur and Manandhar (2003), Shazia et al., (2004), and Zida et al., (2008) that the grains of these crops are highly susceptible to diseases as they act as a source of stored nutrients for fungi. Percent pathogen frequency of seed-borne fungi was higher in groundnut $73.0 \%$ in Fshaye-Areza and minimum in sorghum $15.3 \%$ in Abdu-Hamelmalo.

The major fungal diseases appeared at different phenological stages of on various crops (local varieties) in sub-zone Hamelmalo under natural field conditions in 2011 (Syed, 2013) were leaf spot of peanut (Passalora personata - early leaf spot and Passalora arachidichola - late leaf spot), rust of pearl millet (Puccinia penniseti), downy mildew of pearl millet (Sclerospora graminicola), anthracnose of sorghum (Colletotrichum graminicola) and covered smut of sorghum (Sphacelotheca sorghi). The results are in agreement with earlier works of Chaudhary (1985), Gwary et al., (2007), Kausar and Nayeemullah (1957), Mirza (1982) and Thakur et al., (1998). On average, the maximum leaf spot disease incidence was recorded in all phases in 'Musa Local variety' (50.32\%) compared to other local varieties Ibrahim (49.52\%), Adem (38.27\%), Ahmed (49.16\%) and Idris (38.96\%) local varieties. Incidence percentage of leaf spots may be dependent on growth stages and prevailing climatic conditions. These observations were well in conformity with the earlier studies by Pande et al., (2004). 
The average of three weeks interval survey revealed that the maximum percentage of disease incidence of pearl millet downy mildew was $9.72 \%$ in Ibrahim Local variety followed by $9.59 \%, 7.76 \%$ and $4.53 \%$ in Idris Local variety, Ahmed Local variety and Adil Local variety respectively. The results of this study corroborate the findings of Nene and Singh (1976), Williams (1984) and Hash et al., (1999). The disease incidences of rusts $(18.65 \%)$ and sorghum covered smuts $(27.88 \%)$ were very high in Idris Local variety at seven days interval. Ngugi et al., (2002) assessed the disease intensity due to covered smut as more than $30 \%$ in 42 to $43 \%$ of the fields surveyed. The results are also in accordance with the report of earlier works by Nutsugah et al., (2007).

Six fungal species i.e., (Alternaria alternata, Aspergillus niger, Fusarium moniliforme, Penicillium oxalicum, Helminthosporium and Rhizopus) were isolated from the sorghum seeds collected from five villages viz., Basheri, Hamelmalo, Hitsat, Kurba-bered and Wazentit of Hamelmalo sub-zoba of Zoba Anseba after treating with cow urine, whereas eight species of fungi viz., (Alternaria alternata, Aspergillus niger, Fusarium moniliforme, Penicillium oxalicum, Helminthosporium, Mucor, Rhizopus and Colletotrichum graminicola) were identified in unwashed seeds. It is stated that the fungal pathogen frequency was higher $(35.7 \%)$ in unwashed seeds and lower (14.7\%) in the cattle urine treated seeds. Therefore, it is clearly indicated that treatment with cow urine was found more effective for minimizing seed borne fungal pathogens than water treatment (Bisrat et al., 2014).

One of the reports of Syed et al., (2015) stated that, fungi such as Alternaria alternata, Aspergillus flavus, Aspergillus niger, Colletotrichum graminicola, Fusarium moniliforme, Helminthosporium sorghicola,
Mucor spp., Penicillium oxalicum and Rhizopus spp. were isolated from the sorghum variety HACNL (Hamelmalo Agricultural College New Line). In case of application of botanical and fungicides, the aqueous leaf extracts of Calotropis sp showed more efficacy followed by the extracts of Allium cepa and Lantana camara. Figure 1 clearly shows that the effect of fungicide (ridomil) and botanicals on fungal colony units $(c f u)$ formation. Calotropis sp. had shown more suppressive effect on all fungal flora growth, while the least mycoflora formation recorded for ridomil treatment. Both extracts of Lantana camera leaves and Allium cepa had shown less $c f u$ in-vitro, whereas, untreated seeds showed highest $c f u$ especially it was recorded abundantly in the growth of Aternaria alternata, Helminthosporium sorghicola, Aspergillus niger and Mucor spp.

The major diseases recorded in Hamelmalo region were damping-off, early blight, late blight and powdery mildews on tomato. Disease incidence as high as $95.13 \%$ and disease severity was noticed $87.91 \%$. In some of the fields of Hamelmalo the incidence rate is reached up to $95.31 \%$ in 39 days of time. In one of the surveys (Syed, 2014) done in tomato growing areas of Hamelmalo during November 2013 to March 2014, the most commonly observed diseases were early blight (Alternaria solani), late blight (Phytophtora infestans), wilt (Fusarium spp.) and powdery mildew (Oidium neolycopersici). The most common insect pests were African boll worm (Helicoverpa armigera) and white fly and fruit borer Tuta absoluta. The results revealed that after three observations with a weekly interval, the overall maximum percentage of disease complex of powdery mildew and early blight of tomato was recorded in the Tsebab village fields $71.60 \%$ and minimum in the fields of Abderes $62.60 \%$. The incidence percentage may be depending on growth stage and prevailing climatic conditions for the 
incidence and development of disease (Douglas, 2003). The maximum and minimum disease incidence of powdery mildew was found in the village of Genfelom (38.96\%) and in Awrari village (13.42\%) respectively whereas; early blight alone was very severe in fields of Tsebab village (41.27\%).

In a pathological survey (Sethumadhava Rao, 2016), conducted in two seasons, i.e. autumn (Qewi) Season (August to November) and Winter (Hagay) Season (January to March) on the vegetable crops of tomato and chillies which were grown in selected five villages, i.e. Wazntet, Basheri, Awrari, Genfelom and Hamelmalo of sub Zoba-Hamelmalo were early blight and late blight, bacterial wilt, fusarial wilt and blossom end rot; and infestations caused by insect pests such as tomato borer and Septoria leaf spot rarely found. Powdery mildews were observed only in Wazntet and Genfelom villages. Damping off, yellowing leaf and leaf curl were observed in Awrari, Genfelom, Basheri and Hamelmalo villages.

This survey clearly stated that in Basheri village, the lowest percentage of disease incidence (disease complex) with $59.7 \%$ was found at seedling stage, whereas, the highest percentage of disease incidence with $97.8 \%$ occurred at fruiting stage of tomato; and the high disease severity with $82.9 \%$ was recorded, in Autumn (Qewi) season. This shows that, the mean average disease intensity was $77.23 \%$ and almost $3 / 4^{\text {th }}$ of tomatoes cultivated in those villages were infected at a particular growth period of the crop.

It is recorded that the mean average disease severity of chillies was $46.67 \%$ at any growth stages in sub Zoba Hamelmalo, except in the village Basheri that was recorded as extremely severe $(75.3 \%)$. The maximum range of disease incidence and severity reported in both Basheri (94.90\%) and Gonfelom (95.50\%) during autumn (Qewi) season. In both vegetable crops, tomatoes and chillies, the percentage of disease incidence showed more than $77 \%$ in all villages during Hagay season but the severity was observed as between 20 and $60 \%$. The reasons for those results are low/no educational level among farmers, no proper irrigation/cultivation practices, unavailability of fertilizers and chemicals for controlling the diseases.

In an intensive survey that was conducted in five villages in sub-zoba-Hamelmalo (Hamelmalo, Genfelom, Zeron, Genfelom, Wazantet and Basheri), 5 villages in sub-zobaAdi-Tekeliezan (Adi-Tekeliezan, Dekemhare, Golagul, Melati and Dekighebru) and 3 villages in sub-zoba-Hagaz (Hagaz, Derotay and Hagaz Agro Technical School) on different vegetable crops in 2016, early blight (Alternaria solani), powdery mildew (Leveillula taurica), late blight (Phytropthora parasistica), leaf curl virus (tomato leaf curl virus disease-TLCV), blossom end rot (Botrytis spp.) on tomato; downy mildews (Peronospora spp.) and purple blotch on onion; wilt (bacterial and Fusarium spp.), anthracnose (Colletotrichum spp.), late blight, collar rot and scab on potato were noticed. And leaf minor, fruit borer (Helicoverpa armigera (L.), whitefly (Bemisia tabaci), African boll worm (ABW-Helicoverpa armigera), aphids (Aphididae; Order Homoptera), cutworm, potato tuber moth, spider mites (Tetranychus urticae (Koch), jassids, less wing bug and thrips were also observed as the major insect pests (Syed et al., 2016a). Transmission of the virus by these insect pests, leads to the incidence of leaf curl disease and also serious in some of the crops. On one hand, leaf curl virus and powdery mildews appeared in tomato and chilli; collar rot in potato; powdery mildews in zucchini and carrot almost in all villages where the crops are grown. On the other hand, percentage of severity prevailed due to 
whiteflies and infestation by fruit borer and aphids and registered in all grown crops of sub-zoba Hamelmalo. Tomato and okra showed low to medium percentage of disease severity. Powdery mildew was recorded medium to high in Hagaz and low to high in Derotay. Diamond back moth (Plutella xylostella) on cabbage; cabbage butterfly on cabbage and zucchini; cutworms (Agrotis spp.) on potato; and $\mathrm{ABW}$ on tomato appeared as very common pests. Among all vegetable crops, tomato, okra and chilli crops were more affected by fungal diseases and insect pests compared to other vegetable crops. This intensive survey revealed that there was a heavy toll of pathogens causing powdery mildews and the disease incidence was high in tomato $(65 \%)$, chilli (65\%), zucchini $(60 \%)$ and carrot (70\%). Hamelmalo and Genfelom villages experienced almost all types of diseases and insect infestations in all crops.

In the similar survey, the farmers were interviewed based on a developed questionnaire for knowing cultivating crops in the area, varieties, husbandry practices, diseases and pests of the crops, management practices and farmers' educational level. About 34.88 to $62.50 \%$ of farmers were using the locally available seeds, but $65.51 \%$ of growers by the seeds from the market. The vegetable growers use the potato varieties Ageba, Sudan White, Red and Yemani; tomato variety Sumberson and Margelob and okra variety Bloctihona. About $51.72 \%$ of farmers use irrigation and the rest of 49.27 per cent depend on rainfed cultivation. Most of the farmers do hand weeding, 5-6 times during the crop season. In sub-zobas Hamelmalo (58.06\%), Adi-Tekeliezan (89.65\%) and Hagaz (81.25\%) of farmers use cow dung ash as seed treatment (Syed et al., 2016b).

In a group discussion conducted in three subzobas (Subzoba-Hamelmalo; subzoba Hagaz and Subzoba- Adi-Tekeliezan) with 33 farmers to collect quantitative information on various practices and managements, Zolpho and ash were used in Hamelmalo. Drusban/ chloro-pyrifos $45 \%$ EC, malathion $57 \%$ EC, dimethoate $40 \%$ EC, Focus, cypermethrin $25 \% \mathrm{EC}$, redomil and mancozeb were used in Hagaz. And only dimethoate and sulphur dust were applied in Adi-Teklezian for controlling the diseases and insect pests as well. Farmers of this zoba are not aware of the methods of application of the chemical as per the directions given on the pack, but some of the farmers measured the chemical with one lid/cap (20cc) of the bottle per 201 water (Naqvi et al., 2017). Majority of the vegetable growers used oxen for ploughing the field for cultivation. Due to the paucity of seed sources farmers buy the seed from the neighbourhoods and irrigation was done through wells where they get adequate water. The discussion showed that due to the lack of proper crop husbandry practices and lack of awareness of usage of chemicals various infections as well as infestations are caused.

Medhanie et al., (2017) reported that the fungal occurrence and identification of mycoflora in vegetable cultivating rhizosphere soils from seven vegetable crops (tomato, potato, chili, okra, eggplant, lettuce and Jute mallow) from six villages of three sub-zobas (from sub-zoba Hamelmalo - Hamelmalo village and Kurbaberead village; from subzoba-Hagaz the villages are Hagaz and Derato; and from sub-zoba Adi-Tekeliezan villages are Adi-Tekeliezan and Golagul) for isolation and identification of soil mycoflora. A total of 15 fungi, Alternaria, Arthrobotrys, Aspergillus flavus, Aspergillus niger, Aspergillus terreus, Cladosporium, Curvularia, Drechslera, Fusarium, Mucor, Penicillium, Phoma, Phytophothora, Pyhtium and Rhizopus were identified. The results show that, the maximum occurrence of Cladosporium (44.4\%) and Rhizopus (37.5\%) and the minimum occurrence of Drechslera in 
tomato Adi-Tekeliezan were calculated. Around $20 \%$ of fungal occurrence was recorded in two villages of sub zoba Hagaz. Arthrobotrys, a nematophagous fungus, was identified for the first time in the rhizosphere of chilli of Derato village.

The study of disease and its intensity on grape vines (Vitis vinifera) as conducted at Hagaz Technical School where this crop was commercially grown of Zoba Anseba in 2012 to 2013 (Syed et al., 2013). The most commonly grown varieties of grapes in these areas are viz., Barberia (red), Nero (red), Srah (red), Cabernet (red), Melot(red), Sandioverge (red), Malvasia (white), Scavia (red), Maltopwllichano (red) and Muscata (white). In this investigation it was clearly identified that the Uncinula necator, Plasmopara viticola and Colletotrichum gloeosporioides were causing agents of the common diseases of powdery mildew, downy mildew and anthracnose, respectively. The $39.05 \%$ (high) disease severity was observed due to powdery mildew where as $1.43 \%$ (low) was from anthracnose at 21 to $50 \%$ level of disease severity index. And maximum disease incidence $(100 \%)$ was due to powdery mildew followed by downy mildew $(67.43 \%)$ and anthracnose $(31.92 \%)$.

In one of the important surveys done on citrus in three sub-zones i.e. Hamelmalo, Hagaz and Elabered of Zoba-Anseba from 2014 to 2015, foot rot disease caused by fungi (Phytophthora spp.) was recorded (Syed et al., 2016c). The characteristics of this disease are gum exudates from gum pockets (pink-orange coloured blisters) located on trunks. Gradually, root system, the trunk below and above the soil line, branches, leaves and fruits are affected and it was very severe in the rainy season.

Citrus crops i.e., orange, lemon and mandarin showed highest incidence of foot rot in Hagaz, i.e. $81,91.5$ and $80.6 \%$ and the lowest incidence was found in Hamelmalo i.e. 52.7, 30.1 and 59.8 per cent respectively. It was observed that the highest disease severity was noted in Hagaz region and the lowest was recorded in sub-region Elabered. The disease incidence $95.83 \%$ was recorded in Technical School area and $90.90 \%$ was noted in Hagaz (Gebina) area on oranges. The Mandarin fruit crop growing in the Technical School area showed the percentages of disease incidence $91.90 \%$; $30.15 \%$ in lemon of Hamelmalo (Wazentet); and $38.33 \%$ in orange of Elabered (Girat Peteros). In lemon highest disease was recorded at Hagaz Technical School and Hagaz (Daerotiy) i.e. 95.74 and 90.90 per cent respectively. The appearance of this phenomenon may be due to relatively warm weather and close spacing among plants; farmers of Hagaz were not careful in the field operation with proper pruning. The farmers also do not follow the proper management practices due to a lack of knowledge.

Growing of cut roses was started by the Eritrean farmers around 40-45 years ago. Now this country is capable for producing cut roses on a large scale and (70\%) were distributed for local market to Asmara flower shops and 30\% is sent for export to Saudi Arabia (Fitwi et al., 2003). The government of Eritrea established green houses in MaiSirwa in 2009, at an area of 8.2ha. They are located $13 \mathrm{~km}$ North West from Asmara, at $15^{\circ} 23^{\prime}$ north latitude and 380 54' east longitudes and an elevation of 2300 meter above sea level. The annual rainfall of the area ranges from $4000 \mathrm{~mm}$ to $600 \mathrm{~mm}$ and annual mean of maximum and minimum temperature are 4.3 to $25.5^{\circ} \mathrm{C}$ (Ministry of Agriculture, 2015).

A pathological survey was done at Asmara flowers Company (MaiSirwa) during the years of 2015 and 2016 (Awet et al., 2016). In MaiSirwa there are two types of greenhouses i.e., greenhouse-1 which includes eight 
cultivars (High and Magic, Marie Claure, Tropical Amazone, Aqua, Bordeaux, Upper Class, Avalanche and Poisson) of three years and eight months old and greenhouse-2 that includes seven cultivars (namely: Avalanche,
Gold strike, Contrast, Wham, Top Secret, Upper Class and Poisson) of ten months old, which were introduced from India (Zoba Maekel Admin, 2014).

Fig.1 Total potential and cultivating land in Eritrea

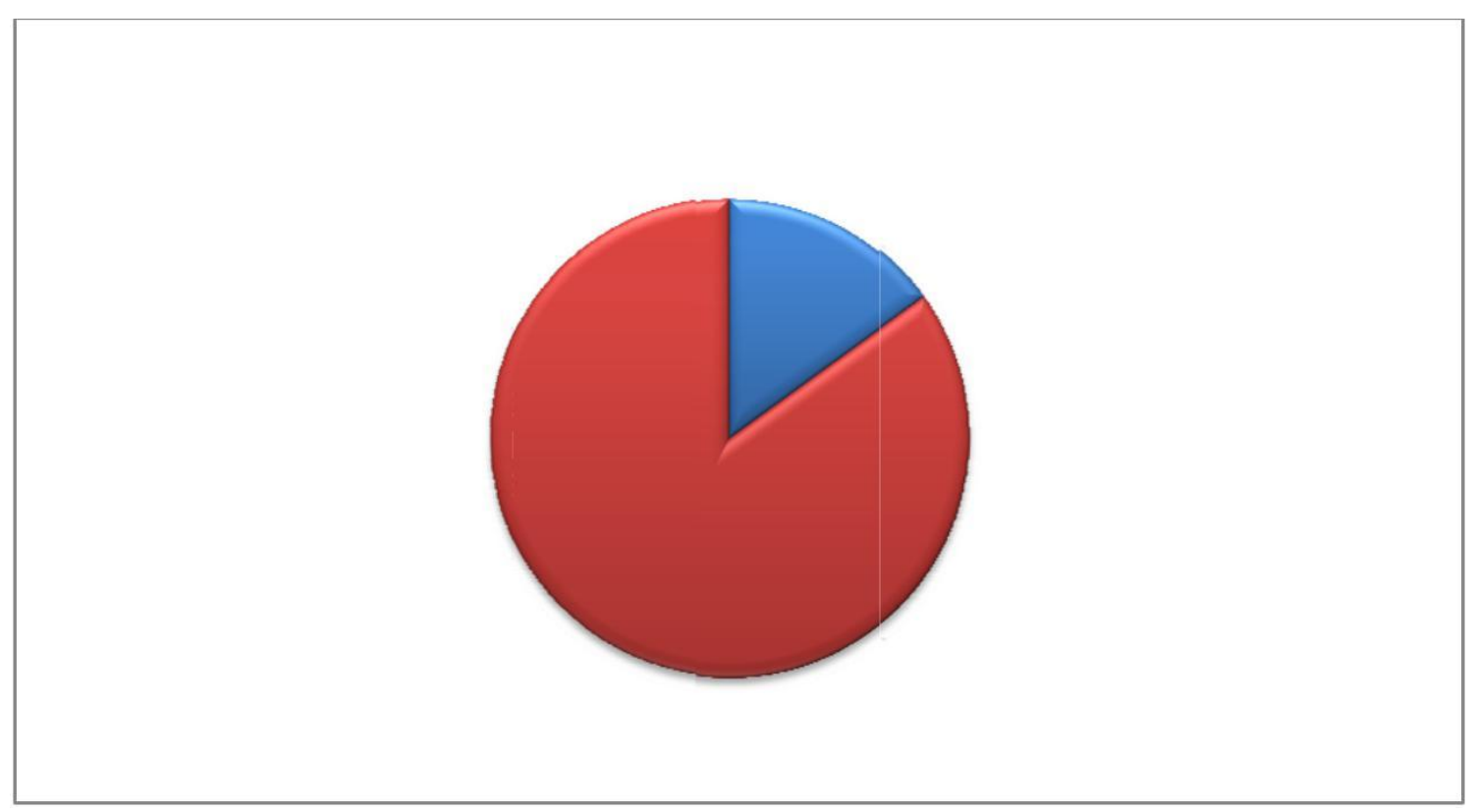

Fig.2 E ritrea and the sub-zobas in Zoba-Anseba

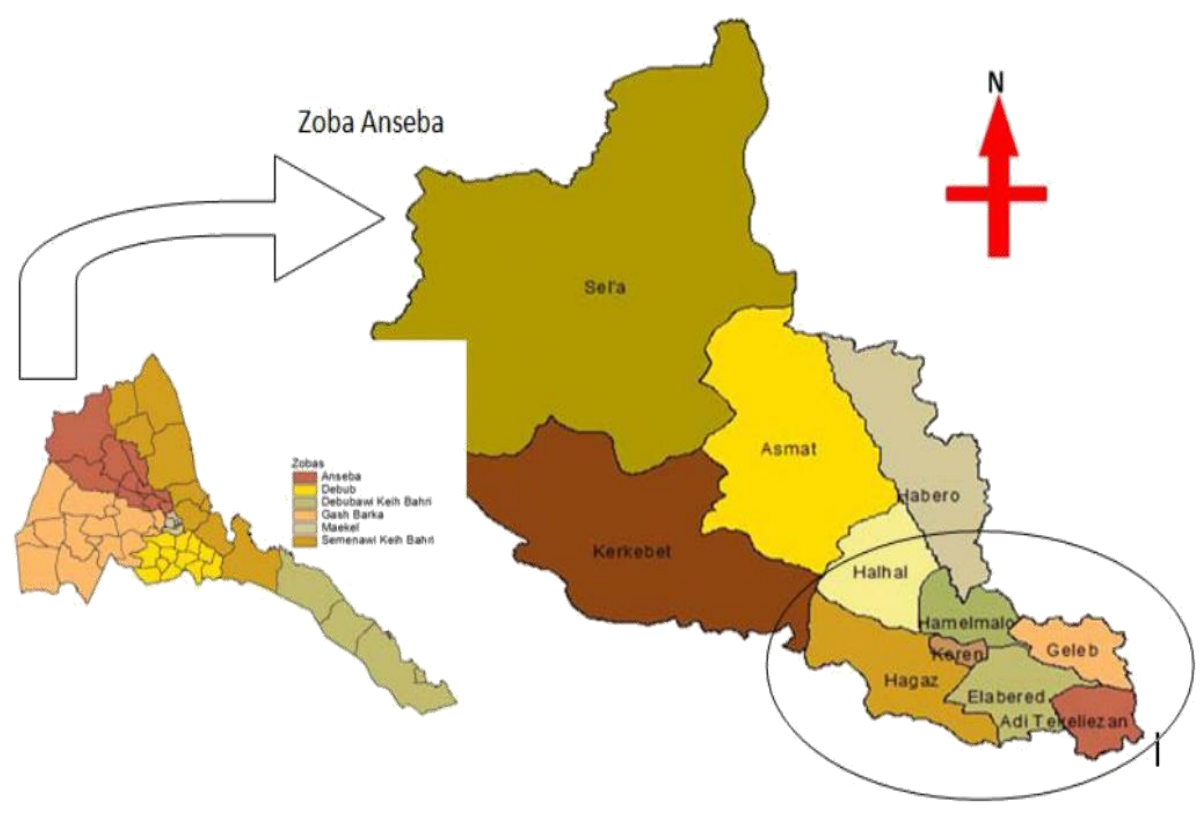


Diseases causing by pathogens on Various Crops in Zoba- Anseba

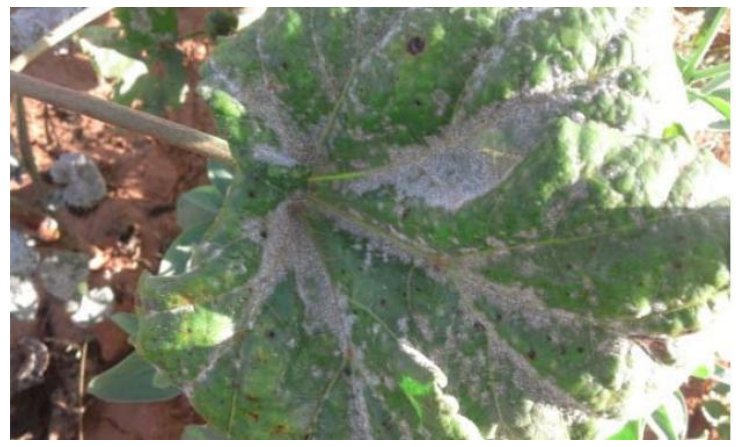

Powdery mildews on okra

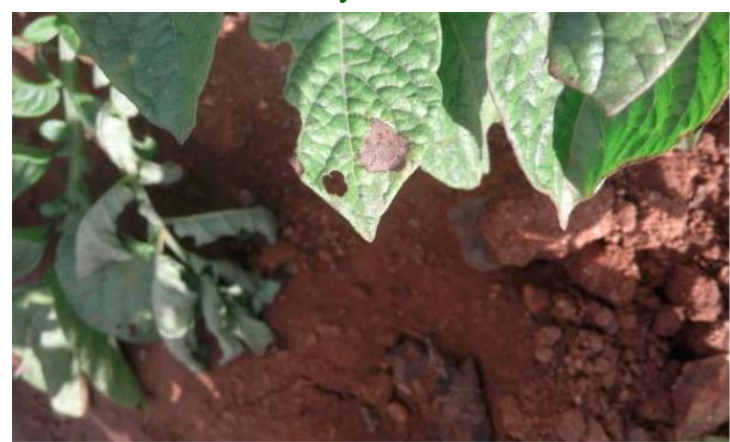

Blight on potato

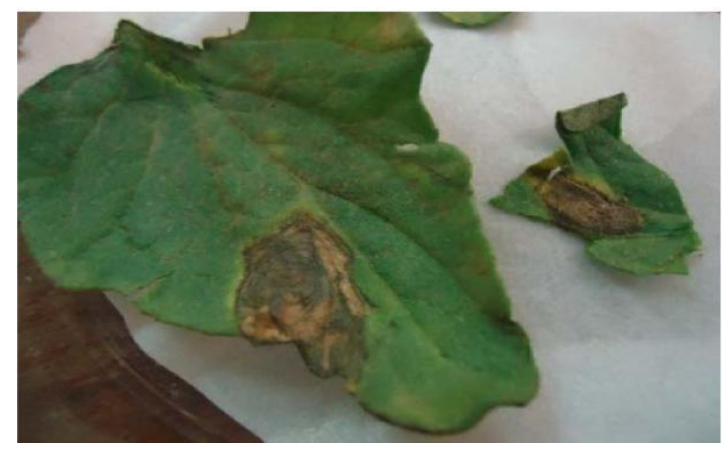

Early blight on tomato

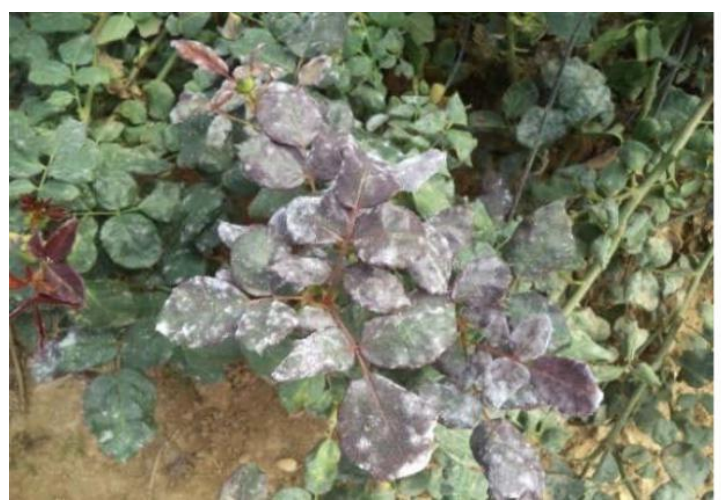

Powdery mildew on the Rose

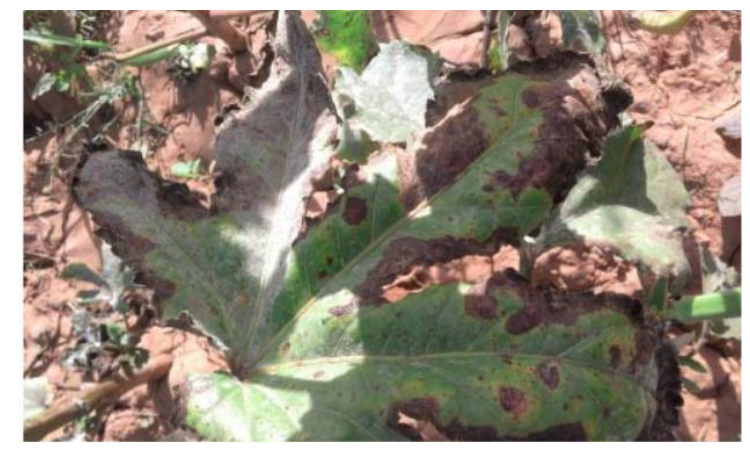

Blight on okra leaves

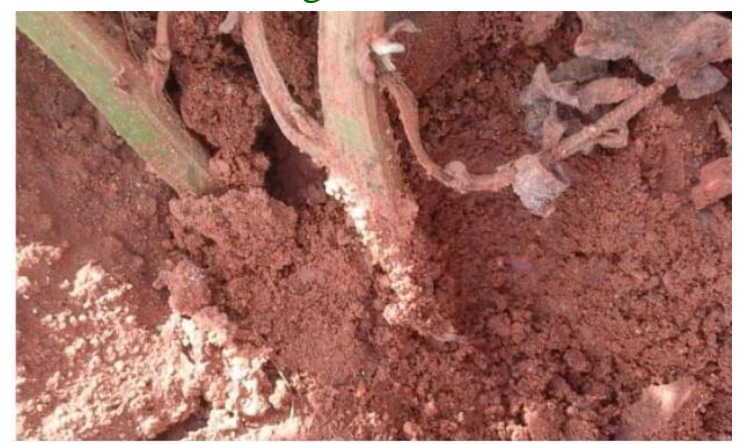

Collar rot in tomato

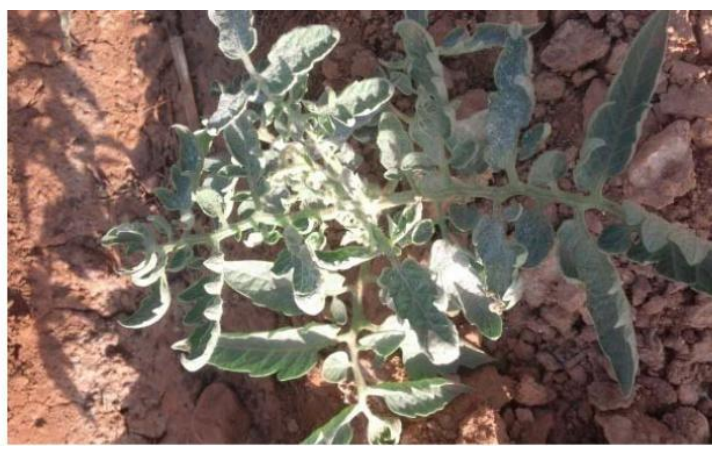

leaf curl on tomato plant
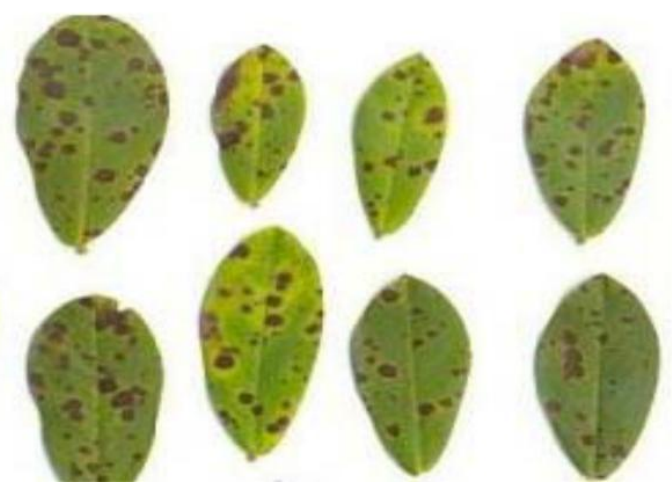

Leaf spot in groundnut 

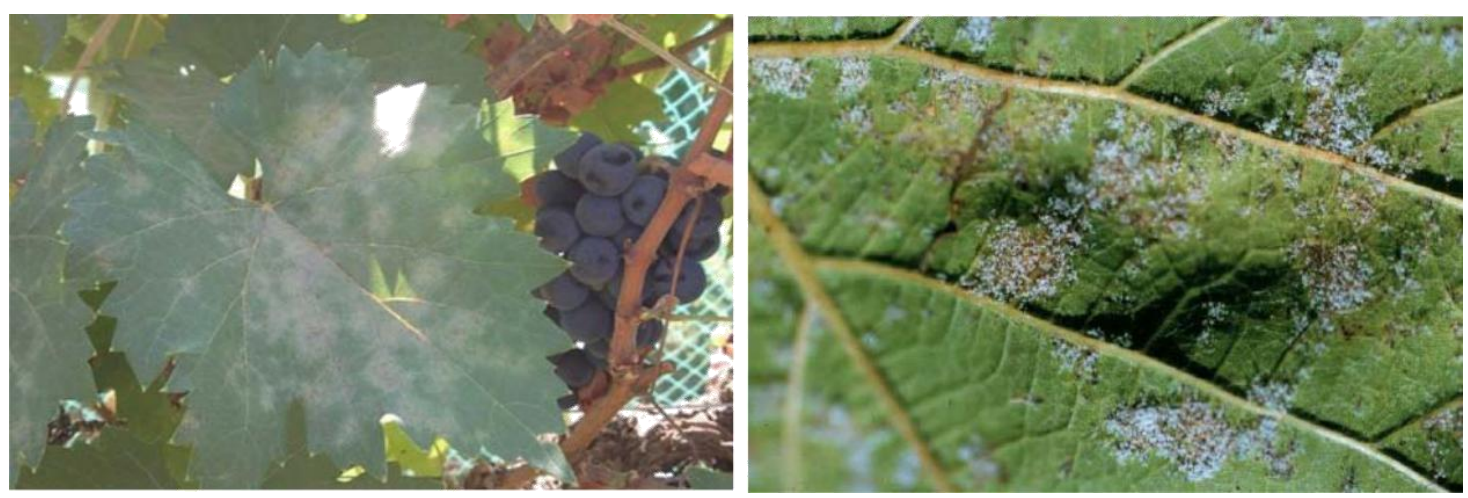

Powdery mildews and Downy mildews on grape leaf

Microscopic images of various fungal pathogens

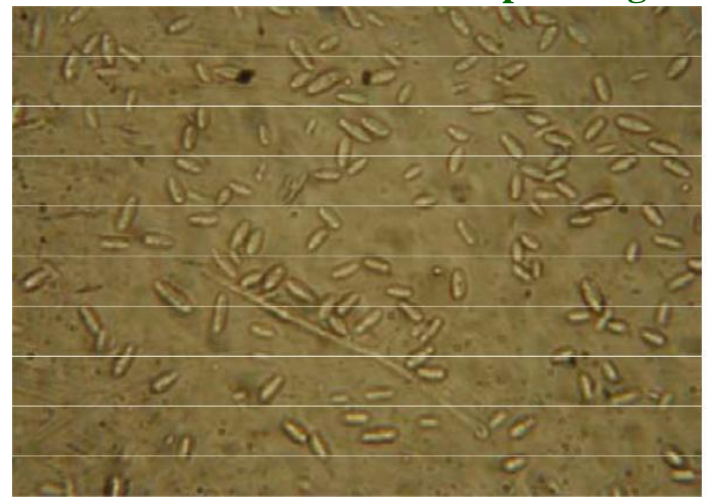

Colletotrichum graminicola

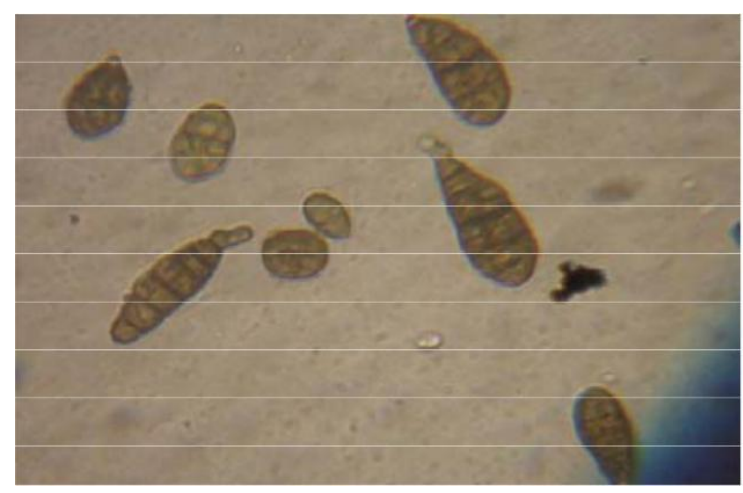

Alternaria alternata

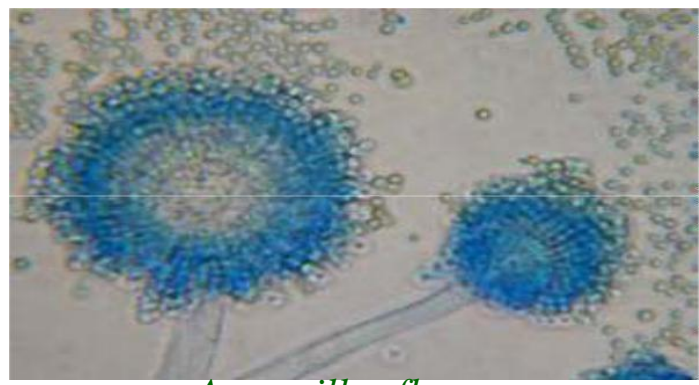

Aspergillus flavus

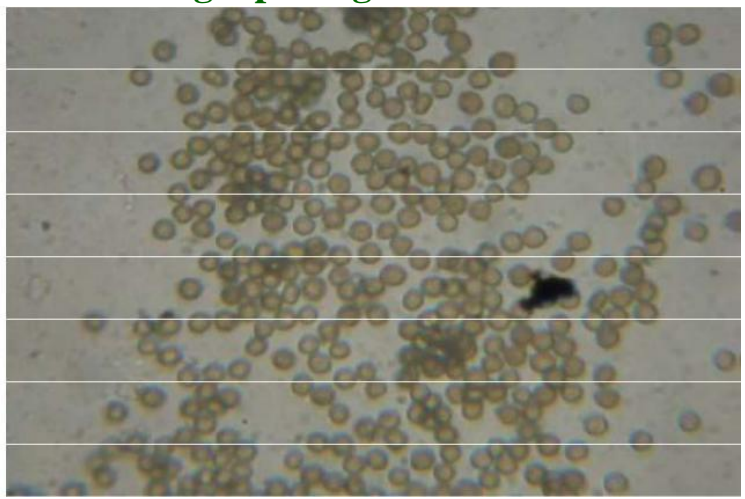

Sphacelothica sorghi spores

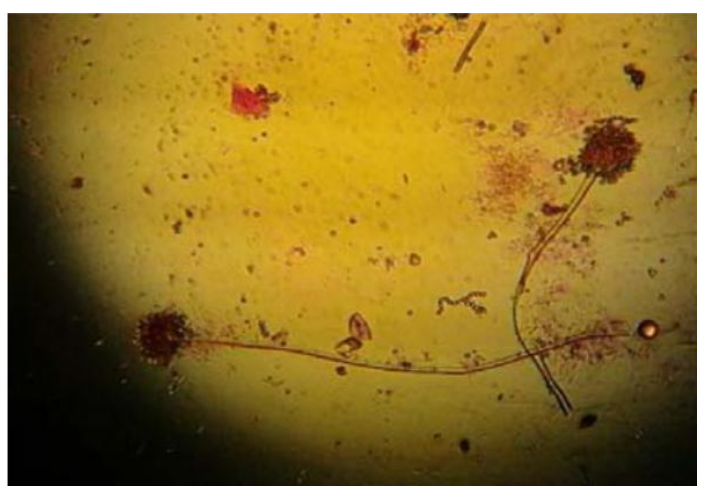

Aspergillus niger

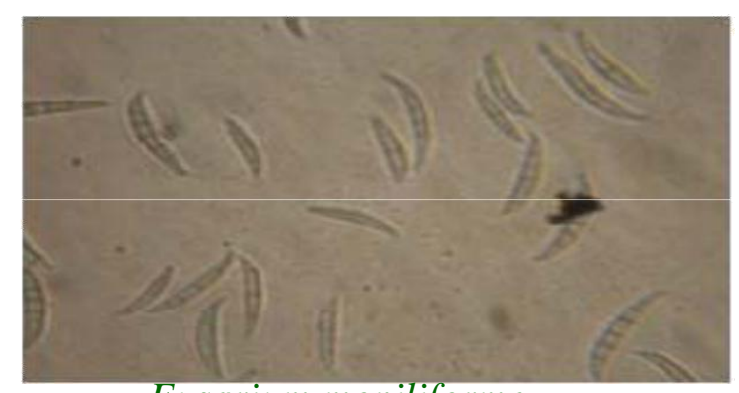

Fusarium moniliforme 


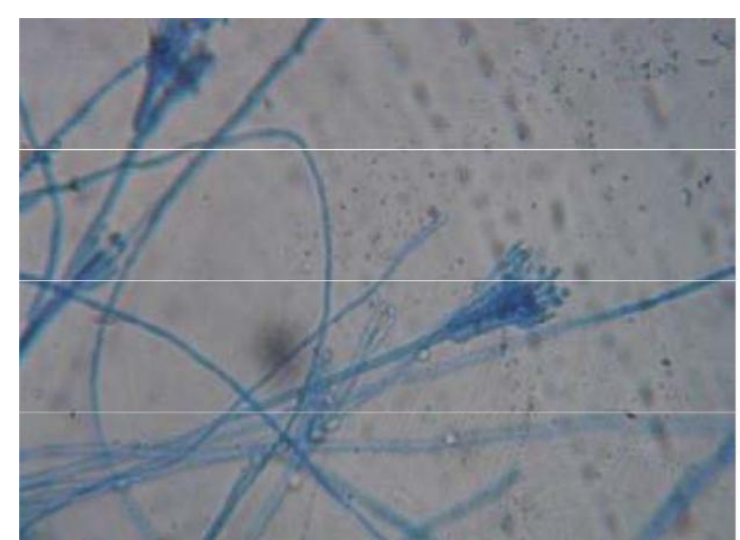

Penicillium oxalicum

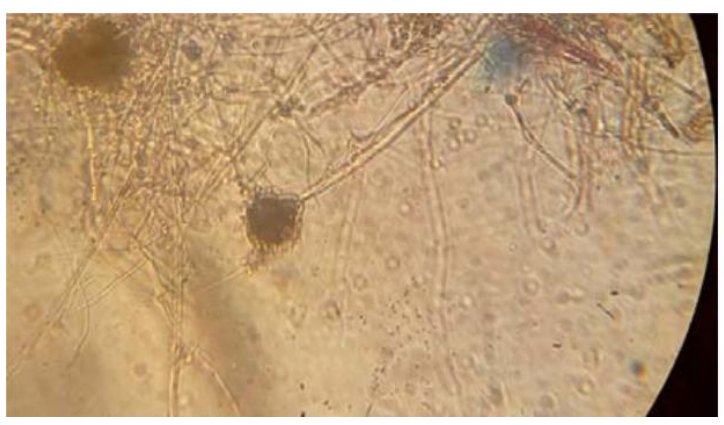

Aspergillus terreus

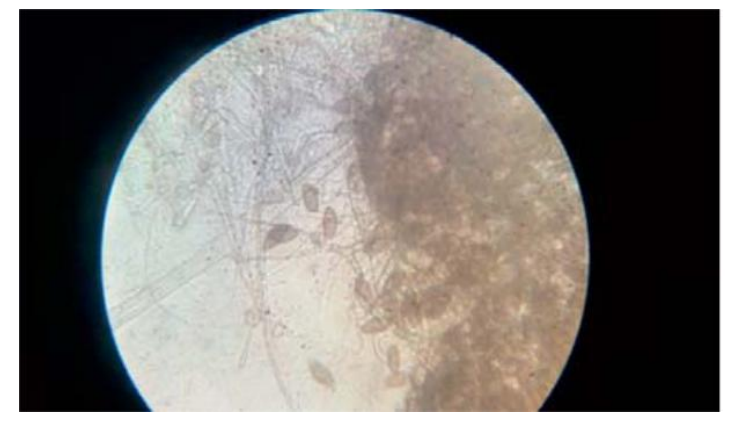

Curvularia
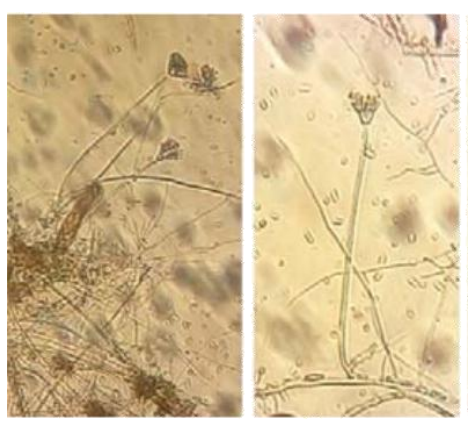

Penicillium
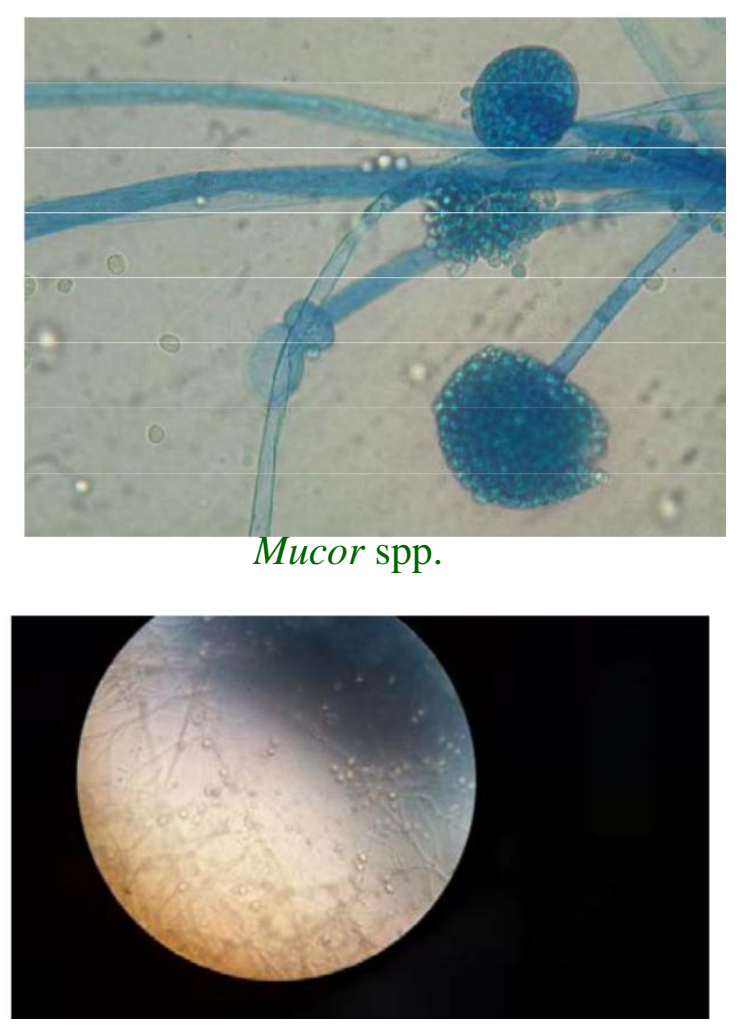

Cladosporium

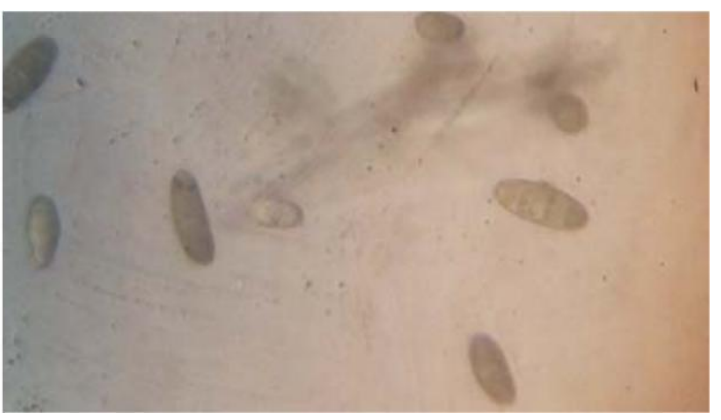

Drechslera

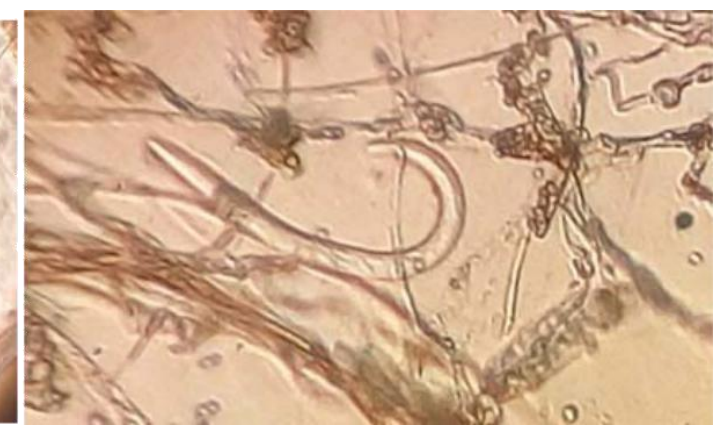

Arthrobotrys 


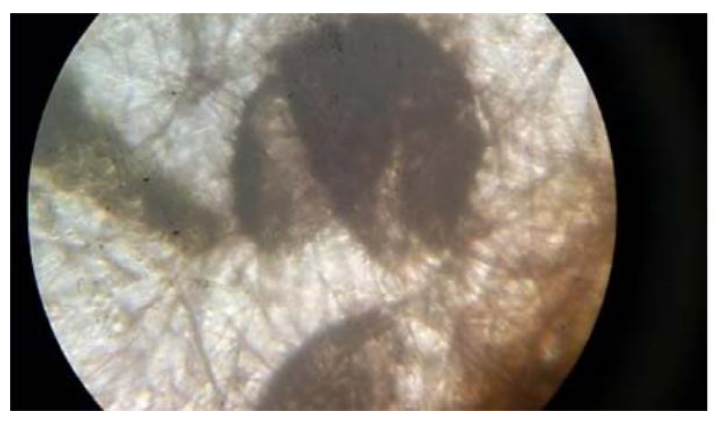

Phoma

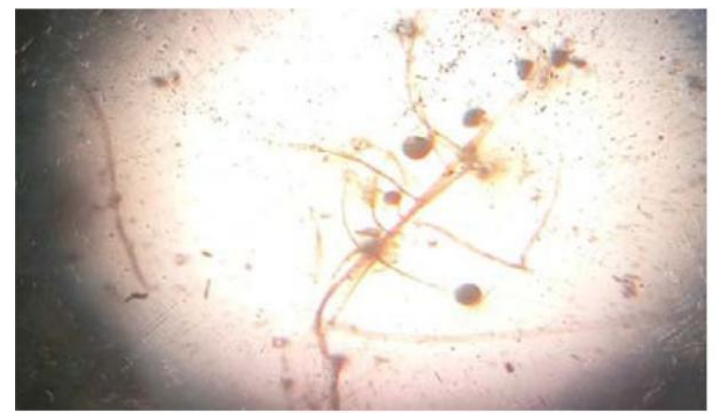

Pyhtium

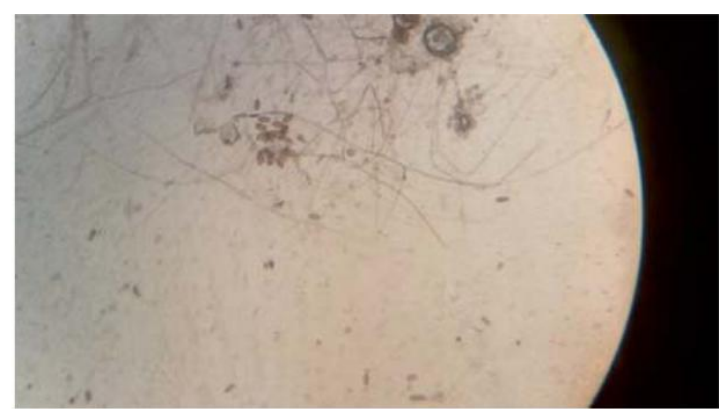

Phytophothora

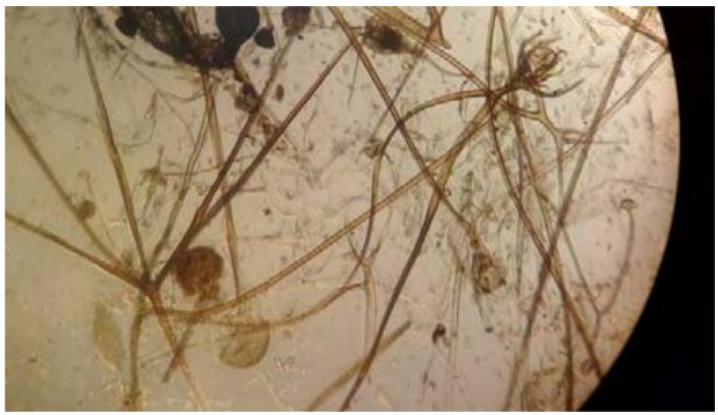

Rhizopus

Infestations causing by insect pests on Various Crops in Zoba- Anseba
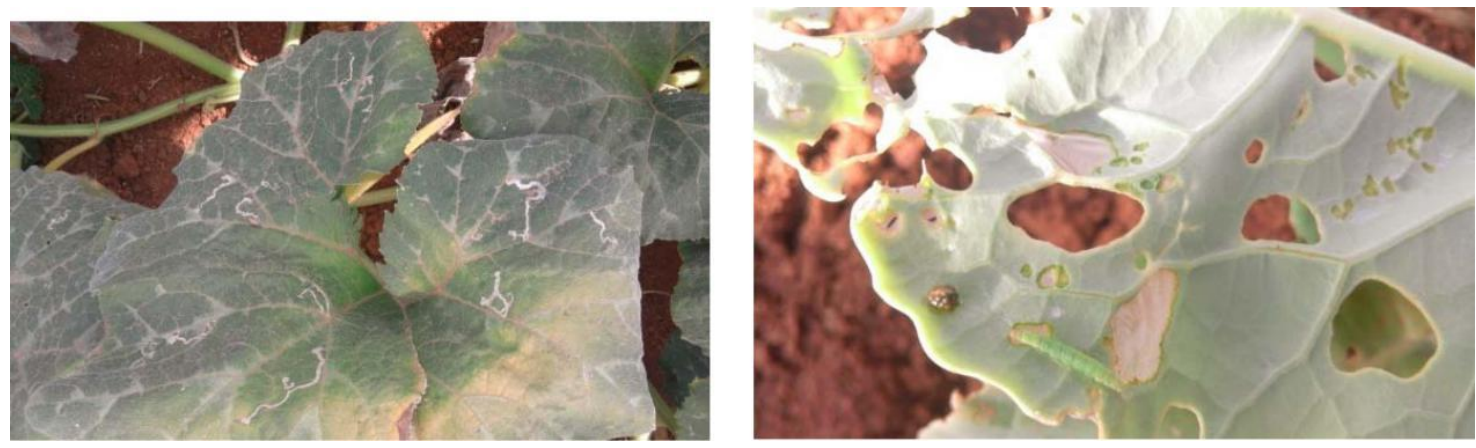

Leaf minor and
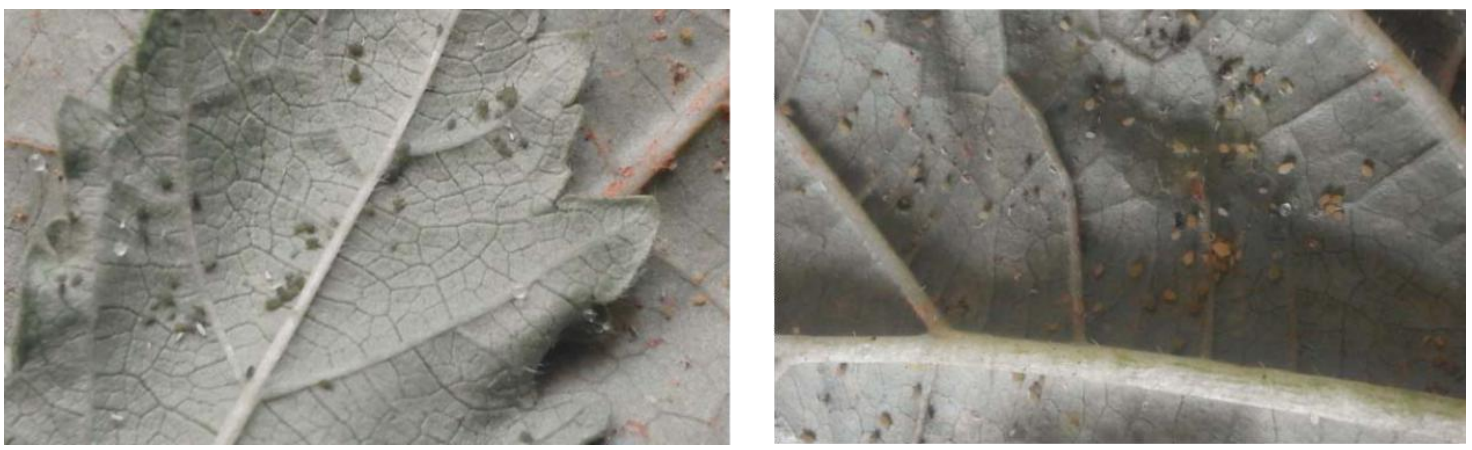

Aphids on leaf 

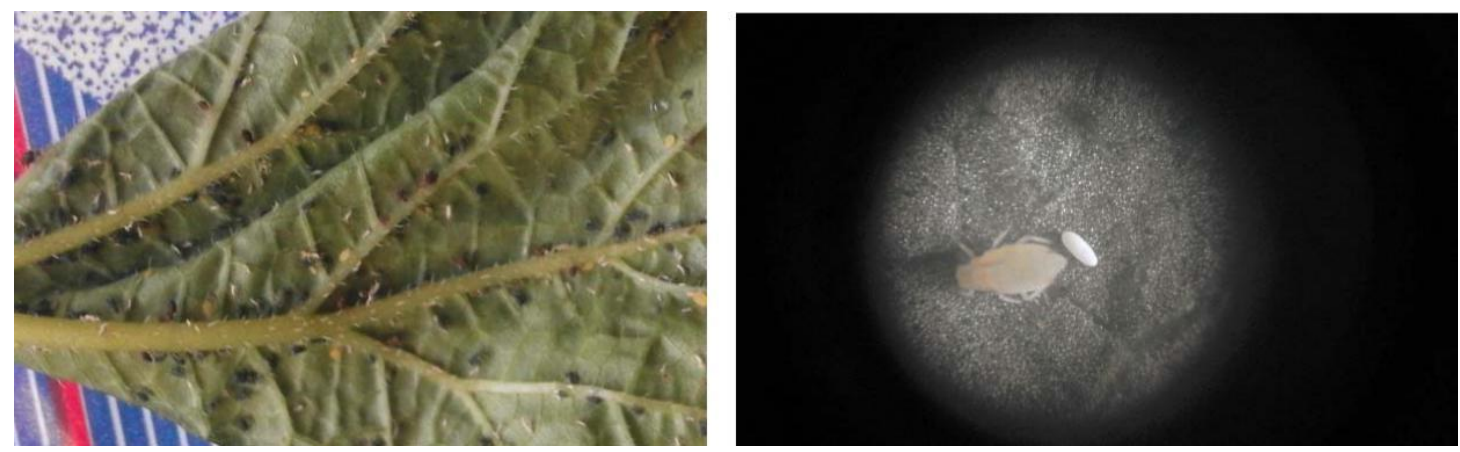

Whiteflies on leaf and under microscope
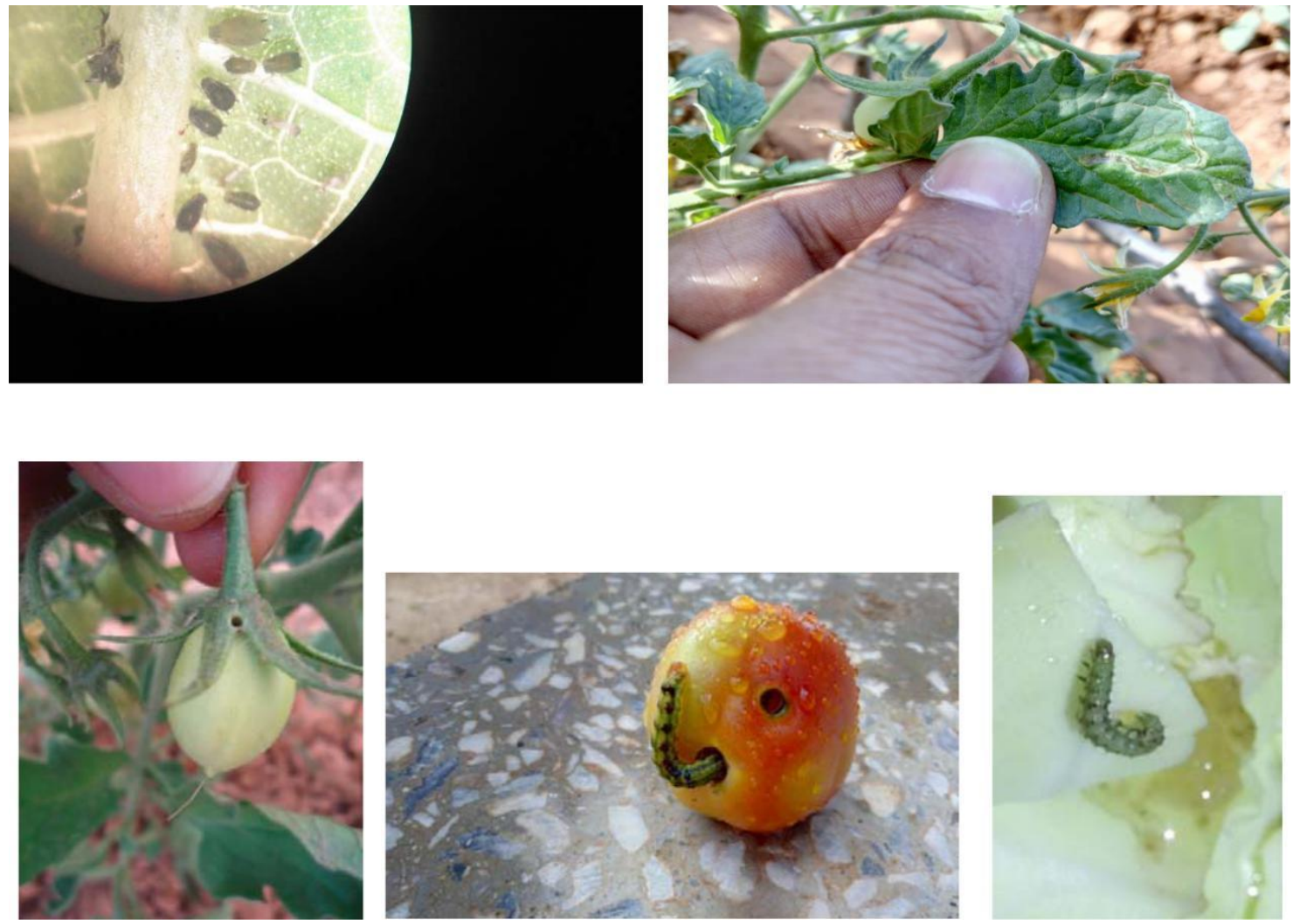

African boll worm (ABW) Helicoverpa armigera

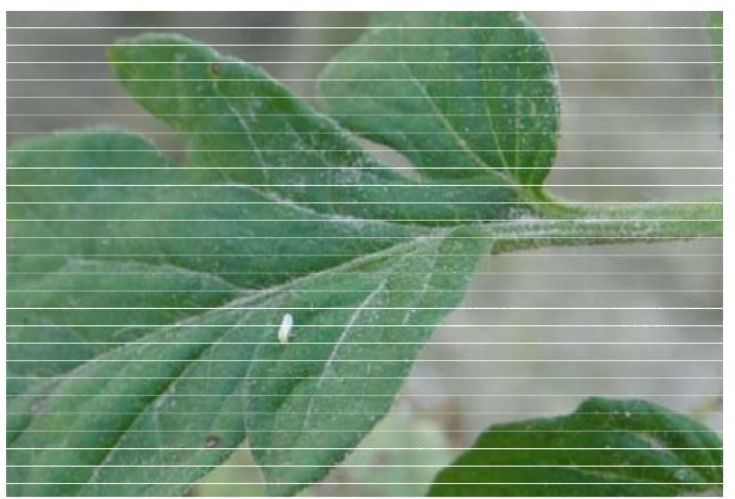

Bemisia tabaci on tomato

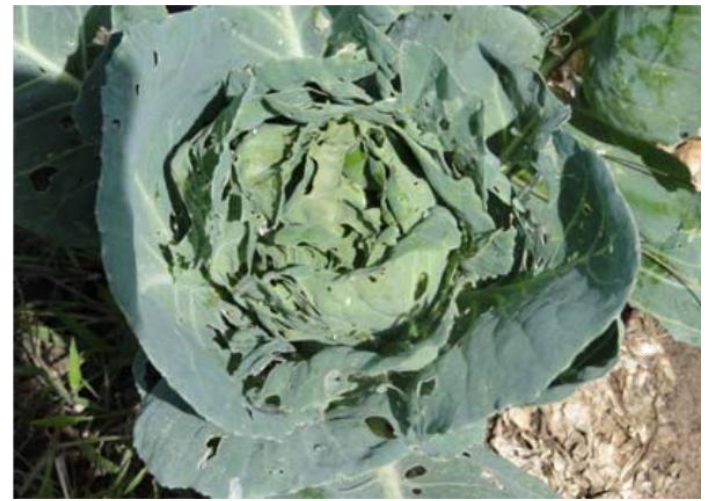

Diamondback moth, Plutella xylostella 
Fig.3 The effect of Ridomil and Plant aqueous extracts on the growth of Colony Forming Units in sorghum variety HACNL

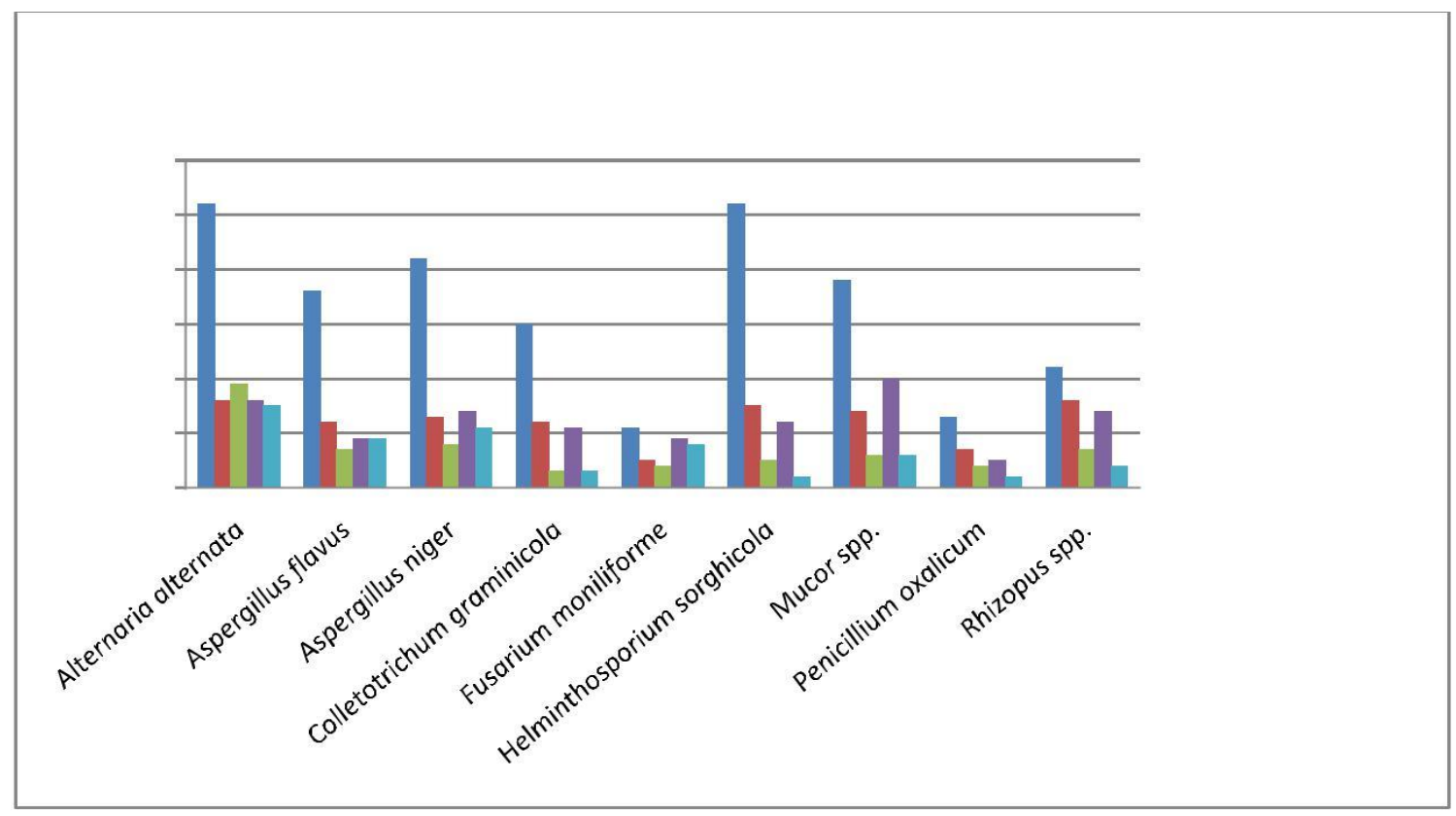

In Eritrea powdery mildew is one of the most harmful fungal diseases on roses, both in the garden as well as in the greenhouses. It is caused by a special form of Sphaerotheca pannosa (Wallr.) de Bary f. sp. rosae. Awet et al., 2016 survey report revealed that during the autumn season the disease incidence and severity were calculated was 81.94 to $100 \%$ and 25.83to $86.81 \%$ in greenhouse-I respectively, while, in greenhouse-II disease incidence was 23.33 to $78.70 \%$ and disease severity was 25.11 to $4.66 \%$ recorded. During winter season disease incidence was between 29.44 to $7.77 \%$ and severity was 5.88 to $1.55 \%$ in greenhouse-I, in green house-II it was observed that 34.72 to $10 \%$ and 8.11 to $2 \%$ respectively.

Conclusion and future perspective of the study are as follows:

The main objective of this study was to identify, isolate, and determine various philloplane, rhizosphere fungal and other microbial organisms causing diseases on field and horticultural crops from the zoba-Anseba, Eritrea during the decade of 2007-2017. The surveys and assessments of diseases were done within the zoba-Anseba in different seasons. All the experimental works were done in the Plant Protection Field and Laboratory of Hamelmalo Agricultural College. Based on morphological descriptions, many diseases were reported in selected villages of this region. Field mycoflora (Alternaria alternata, Aspergillus niger, Aspergillus terreus, Fusarium oxysporium, Phytophthora infestans, Rhizoctonia solani and Pythium debaryanum) were isolated in the fields of sorghum crop. Alternaria alternata, Aspergillus niger, Fusarium oxysporium, Penicillium chrysogenum, Phytophthora infestans, Rhizoctonia solani, Rhizopus stolonifer and Pythium debaryanum from the Basheri village from the soils of pearl millet at various phenological stages. Nine fungal species i.e., Alternaria alternata, Aspergillus niger, A. flavus, Fusarium oxysporium, Penicillium chrysogenum, Phytophthora infestans, 
Cladosporium cladosporoides Pythium debaryanum and Rhizopus stolonifer isolated from both pearl millet and sorghum fields. The treatments of $4 \mathrm{gm}$ garlic extract $/ \mathrm{kg}$ seed were found to be most effective showing maximum seed germination $(96.70 \%)$ in sorghum and groundnut.

In an intensive survey that was conducted in sub-zoba-Hamelmalo, sub-zoba-AdiTekeliezan and sub-zoba-Hagaz on different vegetable crops in 2016, early blight (Alternaria solani), powdery mildew (Leveillula taurica), late blight (Phytropthora parasistica), leaf curl virus (tomato leaf curl virus disease-TLCV), blossom end rot (Botrytis spp.) on tomato; downy mildews (Peronospora spp.) and purple blotch (bacterial) on onion; wilt (bacterial and Fusarium spp.), anthracnose (Colletotrichum spp.), late blight, collar rot and scab on potato were noticed. Along with leaf minor, fruit borer (Helicoverpa armigera L.), whitefly (Bemisia tabaci), African boll worm (ABWHelicoverpa armigera), aphids (Aphididae; Order Homoptera), cutworm, potato tuber moth, spider mites (Tetranychus urticae Koch), jassids, less wing bug and thrips as the major insect pests.

The fungal flora of Alternaria, Arthrobotrys, Aspergillus flavus, Aspergillus niger, Aspergillus terreus, Cladosporium, Curvularia, Drechslera, Fusarium, Mucor, Penicillium, Phoma, Phytophothora, Pyhtium and Rhizopus were identified from the vegetable cultivating rhizosphere soils from seven vegetable crops (tomato, potato, chili, okra, egg plant, lettuce and Jute mallow).

Uncinula necator, Plasmopara viticola and Colletotrichum gloeosporioides were the causal agents of the common diseases of powdery mildew, downy mildew and anthracnose, respectively on grape vines (Vitis vinifera). The high disease incidence
(95.83\%) was recorded in Technical School area and $90.90 \%$ was noted in Hagaz (Gebina) area on oranges. The Mandarin fruit crop growing in Technical School area showed the percentages of disease incidence $91.90 \% ; 30.15 \%$ in lemon of Hamelmalo (Wazentet); and 38.33\% in orange of Elabered (Girat Peteros). In lemon highest disease incidence was recorded at Hagaz Technical School and Hagaz (Daerotiy) i.e. 95.74 and 90.90 per cent respectively.

The disease incidence and severity were calculated 81.94 to $100 \%$ and 25.83to $86.81 \%$, in a pathological survey which was done at Asmara Flowers Company in various varieties of roses, during the autumn season.

In conclusion, the report showed that due to the lack of proper crop husbandry practices and lack of awareness of usage of chemicals, various infections as well as infestations are caused. It is recommended that the growers should be made aware or be trained about the diseases and pest infestations by their morphological characteristics. It would be better if a prepared manual or chart is provided showing the symptoms of the diseases and insect pests which cause infestations, so that based on the colour images, the diseases would be identified now and then.

\section{Acknowledgements}

We feel indebted and thankful to the farm manager for providing the field; and to the students, colleagues for their kind gestures and consistent help towards this study. The authors are thankful to the farmers for their cooperation during the survey. The authors are thankful to Laboratory of Plant Protection, and acknowledge the Plant Protection Department, Hamelmalo Agricultural College for extending the facilities and logistic support to carry out the research work. We are 
also grateful to the National Commission for Higher Education, Asmara, Eritrea, Jommo Kenyata University of Agriculture and Technology, Nairobi, Kenya and to the JICA (Japan International Cooperation Agency) for the logistic support.

\section{References}

AATF, (2011). African Agricultural Technology Foundation. Feasibility study on Striga control in sorghum. Nairobi, Kenya.

Abdurahman S (2005). Seed borne pathogens on farmer-saved sorghum (Sorghum bicolor L.) seeds. Journal of Stored Products and Postharvest Research. 2(2), pp. 24-28.

Agarwal V.K and Sinclair, J.B., (1997). Principles of Seed Pathology, second edition, CRS press, New Delhi, 332347.

Aneja K.R (2004). Experiments in Microbiology, Plant Pathology and Biotechnology. Fourth edition, New International (P) limited publishers, India. Pp. 51-58.

Anon (2002). Crop Production- FAO, Rome, Italy, Vol. 35, 158-162.

Anonymous, (1997). Annual average rainfall report zoba Anseba branch, Ministry of Agriculture.

Anonymous, (2000). Ministry of Agriculture Horticulture Division Report, Asmara, Eritrea.

ASARECA (2004). Association for Strengthening Agricultural Research in Eastern and Central Africa (ASARECA), www.asareca.org.

Awet Mulbrhan, Brikity, Aster, Yohana, Sethumadhava Rao and Syed Danish. (2016). Survey of Disease Incidence and Severity of Powdery Mildews on Roses (Rosa Sinensis L.) in Greenhouses in Maisirwa, Eritrea. Asian Journal of Science and Technology,
7(5) pp.2850-2856. Available Online at http://www.journalajst.com

Barnet H.L and Hunter B.B., (1972). Illustrated genera of imperfect fungi. The American Phytopathological society, U.S.A. P.241.

Bhasker R, Bidinger AG, Panduranga FR, Rao V, Negusse A (2000). Report of a survey of downy mildew incidence in farmers' fields in Anseba and Gash Barka Regions and an evaluation of the pearl millet breeding trials and nurseries at the Hagaz research station. ICRISAT, Patancheru, India, and ARHRD, Ministry of Agriculture, Eritrea. Pp. 121-128.

Bisrat W, Helen G, Mihretab A, Serekebrhan G, and Syed Danish Y. Naqvi. (2014). Occurrence of seed-borne pathogens in farm saved seeds of sorghum (Sorghum bicolor) in Hamelmalo sub-zoba of Zoba Anseba, Eritrea. World Journal of Applied Sciences and Research. 4(1) pp 01-05.

Chaudhary GA (1985). Groundnut Crop - A useful crop for Barani areas and sandy lands. Proc. Natl. Seminar on oilseed research and development in Pakistan, May 7-9 1985, PARC. Islamabad. pp. 100-113.

D'Andrea AC, Klee M, Casey J. (2001). Archaeobotanical evidence for pearl millet (Pennisetum glaucum) in subSaharan West Africa. - Antiquity 75(288): 341-348.

Davis DP, Jacobi JC,Backman PA (1993). Twenty-four-hour rainfall, a simple environmental variable for predicting peanut leaf spot epidemics. Plant Diseases, 77: 722-725.

Douglas,S.M.(2003)."Powderymildew of tomato. The Connecticut Agricultural Experimental Station. PP037 (11/03R). Available: http://www.caes.state.ct.us/ FactSheetFiles/Plantpathology/fsppo37f .htm. 
Doyer, L.C., (1938). Manual for the determination of seed-borne diseases. Wageningen, Netherland: International Seed Testing Association, p.59.

Ellis, M.B., (1971). Demataceous Hyphomycetes, Commonwealth Mycological Institute, Ferry Lane, Kew, Surrey, U.K, p. 680.

FAO. (2007). Meharena Edition on tropical fruits imported to Eritrea, p. 22-26.

Grando, S, Ghebretatios, I., Semere, A., Ceccarelli1, S., Hadi Maatougui1, M. El, Niane1 Mustafa, Y., Sarker, A., Abdalla, O., Berhane, T., Abraha, N., Tsegay, S., Isaac, T., Tesfamichael, E., Hailemichael, S., Semere, M., Tafere, T., Weldamlak, A., Haile, A., Mesfin, S., Ghebresselassie, T. (2010). Water Productivity Improvement of Cereals and Food Legumes in the Atbara Basin of Eritrea. PN2 Completion Report: ICARDA and CPWF.

Gwary DM, Obida A, Gwary SD (2007). Management of Sorghum Smuts and Anthracnose Using Cultivar Selection and Seed Dressing Fungicides in Maiduguri, Nigeria. Int. J. Agric. Biol., Vol. 9(2): 324-328. International Seed Testing Association (ISTA) (1976). Seed Science and Technology 4:3-48.

James WC (1971). A manual of disease assessment keys for plant diseases. Canada Dept.Agric. Publication No. 1458:80.

James WC (1974). Assessment of plant diseases and losses. Annual Rev. Phytopathol. 12:27-48.

Javaid, Arshad; Asma Ashraf, Naureen Akhtar, M. Hanif and M. Asad Farooq (2006). Efficacy of some fungicides against seed-borne mycoflora of wheat. Mycopath (2006), 4(1): 45-49.

Kausar AG, Nayeemullah M (1957). Disease problems of groundnut in Khairpur division.Proc. 9th Pakistan Science Conference. pp. 22-23.
Leipzig, (1996). Country report to the FAO International technical conference on plant genetic resource. Prepared by Ministry of Agriculture, Asmara, August 1995.

Lukose CM, Moradia AM, Kunadia BA (2008). Diseases of groundnut in Gujarat and their management. Published Research Scientist (Groundnut). Main Oilseeds Research Station. Junagadh Agricultural University, Junagadh, pp.1-16.

Mario. M.(1997). "Research and development program me horticultural crops, Asmara". p10.

Masum, M. M. I., Islam, S. M. M. and Fakir, G. A. (2009). Effect of seed treatment practices in controlling seedborne fungi in sorghum. Scientific Research and Essay 4(1), 22-27.

Mathur SB, HK Manandhar (2003). Fungi in seeds recorded at the Danish Government Institute of Seed Pathology for developing countries, Copenhagen, Denmark, pp: 825.

Mayee CD, Datar VV (1986). Phytopathometery Tech. Bult. 1. Marathwada Agri. Uni. Parbhani India. pp. 90-91.

Medhanie, E., G. Mussie, A. Selamawit, G. Sethumadhava Rao and N. Syed Danish. (2017). Occurrence and Identification of Rhizosphere Mycoflora of Selected Vegetable Crops Grown in Zoba Anseba, Eritrea. Trends in Biosciences 10(33). Pp.7099-7104. ISSN: 0974-8431,

Mesta, R.K; Bengai, V.I; Kulkarni, Srikant and Goud, S.I, (2009). In vitro evaluation of fungicides and plant extracts against Alternaria helianthi causing blight of sunflower Karnataka J. Agric. Sci., 22 (1): (111- 114)2009.

Mirza MS (1982). Groundnut diseases in Pakistan. In: Groundnut production manual. National training program on 
groundnut 4-8 April, 1982. PARC. Islamabad. Ministry of Agriculture (MoA), (1995). Asmara, August. Ministry of Agriculture MoA (2003). Basic agricultural facts of Anseba Region, Keren. http://www.eritreaembassyjapan.org/dat a. Agronomy in Spate Irrigated Areas of Eritrea.pdf Ministry of Agriculture (MoA) (2012). Annual vegetable production and consumption in Eritrea. Ministry of Agriculture (MoA), Eritrea. (2014). Anonymous: country annual report of total cereal production. (In press).

Naqvi Syed Danish Yaseen, Haile Adugna, Sethumadhava Rao G., Sharma V.K. And Teweldemedhin Belay (2017). Farmers Discussion on Vegetable Crops, Infections and Infestations of Pests and their Management Practices in Zoba Anseba, Eritrea. International Journal of Agriculture Sciences. 9(47). pp.4783-4786. ISSN: 0975-3710 and EISSN: 0975-9107.

Ngugi HK, King SB, Abayo GO, Reddy YVR (2002). Prevalence, incidence, and severity of sorghum diseases in western Kenya. Plant Diseases. 86: 65-70.

Nono-Womdim, R., I.S. Swai, M.L Chadha, K. Gebre-Selassie, and G. Marchoux. (2001). Occurrence of chilli veinal mottle virus in Solanum aethiopicum in Tanzania. Plant Disease 85: 801.

Nutsugah SK, Atokple IDK, Leth V (2007). Prevalence of sorghum diseases in Ghana. Ghana J. Agric. Sci. 40: 119126.

Olkowski, W., Daar, S and Olkowski, H (1995). The gardener's guides to common-sense pest control, The Taunton Press, USA.

Ong, C.A., G. Varghese, and W.P. Ting. (1979). Aetiological investigations on a veinal mottle virus of chilli (Capsicum annuum L.) newly recorded from
Peninsular Malaysia. MARDI Research Bulletin 7: 78-88.

Pande S, Rajesh TR, Rao KC, Kishore GK (2004). Effect of temperature and leaf wetness period on the Components of Resistance to Late Leaf Spot Disease in Groundnut. Plant Pathol. J. 20(1): 6774.

Rathod, L.R., Jadhav M.D., Kanse D.S., D.P. Patil, S.D. Gulhane, Deshmukh P.S. (2010). Effects of fungicides on seed borne pathogen of groundnut International Journal of Advanced Biotechnology and Research, 1 (1), pp 17-20.

Rohrbach DD (2004). Marketing constraints and opportunities for sorghum and millet in southern and eastern Africa. Economics Group, Resource Management Programme, Progress Report 106. Patancheru, Inde, ICRISAT.

Sethumadhava Rao, Syed Danish, Sham Keflemariam, Haben Tesfagergish, Rahwa Tesfamariam, Tomas Habtemariam. (2016). Pathological Survey on Disease Incidence and Severity of Major Diseases on Tomato and Chilli Crops Grown in Sub Zoba Hamelmalo, Eritrea. International Journal of Research Studies in Agricultural Sciences. 2(1). Pp.13-24. www.arcjournals.org

Shazia R, Shahnaz D, Ghaffar A, Shaukat SS (2004). Seed borne mycoflora of groundnut. Pakistan J. Bot. 36 (1): 199202.

Shenge KC (2007). Bacterial speck and bacterial spot disease of tomato in Tanzania: Pathogen characterization, epidemiology and management options. PhD Thesis, Sokoine University of Agriculture, Morogoro, Tanzania, p. 271.

Singh BK, Srivastava M, Narain U. (2003). Evaluation of bio-agents against 
Fusarium oxysporumf. $\quad$ sp. ciceri causing chickpea wilt. Farm Sci. J., 12(1): 48-49.

Singh RS (1998). Plant diseases, Seventh Edition, Oxford \& I.B.H Publishing Corporative Private Limited, New Delhi, India.

Sonawane SS, Pawar NB. (2001) Studies on biological management of chickpea wilt. J. Maharashtra Agric. Univ., 26: 215-216.

Syed Danish Yaseen Naqvi and S. Ahmad. (2012). Efficacy of Trichoderma spp. against fusarial wilts of chickpea (Cicer arietinum L.). Journal of Stored Products and Postharvest Research. 3(4), pp. 52-53. Available online http://www.academicjournals.org/JSPP R,DOI: $\quad$ 10.5897/JSPPR11.050.ISSI 2141-6567.

Syed D.Y.N, Mengesteab T, Robiel, N, Robiel W and Tekle Z. (2012). Efficacy of garlic extract and mancozeb against seed borne fungal pathogen of farmer saved sorghum (Sorghum bicolor) and groundnut (Arachis hypogaea) seeds (2010-2011). Greener Journal of Agricultural Sciences. 2 (2), pp. 22767770.

Syed Danish Yaseen Naqvi. (2013). Prevalence of economically important fungal diseases at different phenological stages of peanut (Arachis hypogaea L.), pearl millet (Pennisetum glaucum L.) and sorghum (Sorghum bicolor L.) in sub-zone Hamelmalo. Journal of Agricultural Economics and Development. 2(6), pp. 237-245. Available online at http://academeresearchjournals.org/jour nal/jaed,ISSN 2327-3151 (C2013 Academe Research Journals.

Syed Danish Yaseen Naqvi, Adil Hameed, Simret Mussie, Yodit Fitsum and Yodit. (2013). Prevalence of Economical Important Diseases of Grape Vines in
Hagaz Agro Technical School of Zoba Anseba in Eritrea. International Journal of Innovative Agriculture \& Biology Research 1(1): 1-8.

Syed Danish Yaseen Naqvi, Shiden T, Merhawi W and Mehret S. (2013). Identification of seed borne fungi on farmer saved sorghum (Sorghum bicolor L.), pearl millet (Pennisetum glaucum L.) and groundnut (Arachis hypogaea L.) seeds. Agricultural Science Research Journals. 3(4), pp.107-114. Available online at http://www.resjournals.com/ARJ. ISSNL:2026-6073. (C2013 International Research Journals.

Syed Danish Yaseen Naqvi, Awet Tesfalem, Bereket Tesfazghi, Gezae Asfeha and Ruta Mangesteab (2014). Survey on Economical Important Fungal Diseases of Tomato in Sub-Zoba Hamemalo of Eritrea. Review of Plant Studies, 2014, 1(4): 39-48.

Syed Danish Yaseen Naqvi, Sethumadhava Rao G, Mehrateab M and Zerai Tesfay. (2015). Comparative Study on Efficacy of Fungicide and Extracts of Lantana camara, Allium cepa and Calotropis sp. against Seed borne Mycoflora of Sorghum. International Journal in Physical \& Applied Sciences. 02 (12). ISSN: 2394-5710.

Syed Danish Yaseen Naqvi, G. Sethumadhava Rao, Feven Michael and Yohana Fitwi. (2016). Isolation of field mycoflora at different growth stages of pearl millet (Pennisetum glaucum) and sorghum (Sorghum bicolor) of Hamelmalo region in Eritrea. Journal of Eco-friendly Agriculture. 11(2): 154-157.

Syed Danish Yaseen Naqvi, Adugna Haile, Sethumadhava Rao, Belay Teweldemedhin and Virendra Kumar Sharma. (2016a). Occurrence and prevalence of diseases and insect pests on vegetable crops in Zoba Anseba, 
Eritrea. Journal of Eco-friendly Agriculture. 12(1): 29-40.

Syed Danish Yaseen Naqvi, Adugna Haile, Sethumadhava Rao, Belay Teweldemedhin, Virendrakumar Sharma and Aggrey Bernard Nyende. (2016b). Evaluation of husbandry, insect pests, diseases and management practices of vegetables cultivated in Zoba Anseba, Eritrea. Journal of Ecofriendly Agriculture 12(1): 47-50.

Syed Danish Yaseen Naqvi, G. Sethumadhava Rao, Bethelihem Kiflemariam, W., Daniel Guesh, G. and Million Eyob, W. (2016c). A survey on incidence and severity of citrus gummosis caused by Phytophthora species in Zoba Anseba, Eritrea. Journal of Eco-friendly Agriculture. 11(2): 158-163.

Thakur RP, King SB (1988). Smut disease of pearl millet. ICRISAT Information Bulletin No. 25, ICRISAT, India. 17pp.

Thakur RP, Pushpavathi B, Rao VP (1998).
Virulence characterisation of single zoospore isolates of Sclerospora graminicola from pearl millet. - Plant Disease 82: 747-751.

Waksman SA. (1922). A method for counting the number of fungi in the soil. J. Bact., 7 (3): 339-341.

Warcup J.H. (1950). The Soil Plate Method for Isolation of Fungi from Soil. Nature. Lond., 1950; 166: 117-118.

Weeks R, Hagan A, Foshee W, Hartzog DL, Everest JW (2000). Peanut pest management scout manual. Alabama co-op. Ext. system. pp. 1-20.

Zida Pawinde Elisabeth, Sereme Paco, Leth Vibeke, Sankara Philippe, Somada Irenee, Neya Adama (2008). Importance of seed borne fungi of sorghum and pearl millet in Burkina Faso and their control using plant extracts. Pakistan Journal of Biological Sciences 11 (3): $321-331$.

\section{How to cite this article:}

Syed Danish Yaseen Naqvi and Sethumadha A Rao, G. 2019. Influence of Pathogens on Disease Development with Various Crops Grown in Zoba-Anseba, Eritrea during 2007-2017: A Report. Int.J.Curr.Microbiol.App.Sci. 8(01): 760-782. doi: https://doi.org/10.20546/ijcmas.2019.801.084 